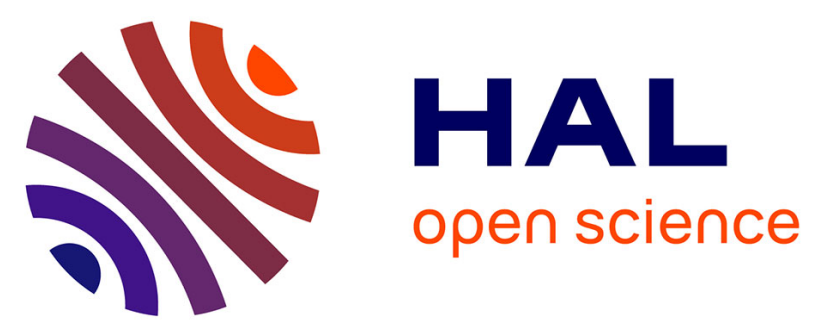

\title{
Tectonic record of strain buildup and abrupt coseismic stress release across the northwestern Peru coastal plain, shelf, and continental slope during the past $200 \mathrm{kyr}$
} Jacques Bourgois, Florence Bigot-Cormier, Didier Bourles, Regis Braucher, Olivier Dauteuil, César Witt, François Michaud

\section{To cite this version:}

Jacques Bourgois, Florence Bigot-Cormier, Didier Bourles, Regis Braucher, Olivier Dauteuil, et al.. Tectonic record of strain buildup and abrupt coseismic stress release across the northwestern Peru coastal plain, shelf, and continental slope during the past 200 kyr. Journal of Geophysical Research : Solid Earth, 2007, 112 (B4), pp.B04104. 10.1029/2006JB004491 . insu-00155036

\section{HAL Id: insu-00155036 \\ https://hal-insu.archives-ouvertes.fr/insu-00155036}

Submitted on 30 Mar 2016

HAL is a multi-disciplinary open access archive for the deposit and dissemination of scientific research documents, whether they are published or not. The documents may come from teaching and research institutions in France or abroad, or from public or private research centers.
L'archive ouverte pluridisciplinaire HAL, est destinée au dépôt et à la diffusion de documents scientifiques de niveau recherche, publiés ou non, émanant des établissements d'enseignement et de recherche français ou étrangers, des laboratoires publics ou privés. 


\title{
Tectonic record of strain buildup and abrupt coseismic stress release across the northwestern Peru coastal plain, shelf, and continental slope during the past $200 \mathrm{kyr}$
}

\author{
Jacques Bourgois, ${ }^{1}$ Florence Bigot-Cormier, ${ }^{2}$ Didier Bourles, ${ }^{3}$ Régis Braucher, ${ }^{3}$ \\ Olivier Dauteuil, ${ }^{4}$ César Witt, ${ }^{5}$ and François Michaud ${ }^{5}$ \\ Received 6 May 2006; revised 14 November 2006; accepted 27 December 2006; published 7 April 2007.
}

[1] This paper presents a combined analysis of geological and geophysical data collected both onshore and offshore along the northwestern Peru forearc area $\left(3^{\circ} 30^{\prime}-7^{\circ} 30^{\prime} \mathrm{S}\right)$, from the coastal plain to the trench axis. Onshore, geomorphic analysis places constraints on the relative importance of eustatic versus tectonic factors in preserving and modifying the uplifted coastal landforms along the coastal plain. Breaking-wave morphologic markers were dated using the in situ produced ${ }^{10} \mathrm{Be}$ cosmonuclide. The data document a tectonic segmentation, allowing us to differentiate two areas with regard to their evolution through time: the northern Cabo Blanco and the southern Paita-Illesca segments. For the past $200 \mathrm{kyr}$, both segments uplifted at high rates of 10 to $20 \mathrm{~mm} \mathrm{yr}^{-1}$ through tectonic pulses coeval with the eustatic deglacial sea level rises of isotope stage 1 and warm isotope substage $5 \mathrm{e}$, respectively. The uplift and related extensive emersion of the coastal plain require high coupling along the subduction zone and/or underplating at depth. Offshore, industry-acquired reflection seismic lines combined with EM12 bathymetric data allow us to investigate the tectonic regime and deformation of the continental margin and shelf. Major dipping seaward detachments control the long-term subsidence of this area. These main tectonic features define a tectonic segmentation. The Talara, Paita, and Sechura segments are identified from north to south. No clear tectonic correlation in time exists between the onshore and the continental margin segmentations, or in space either. The longterm subsidence of the offshore, indicative of subduction erosion working at depth, requires low coupling along the subduction channel at depth. The distribution of permanent deformation along the northern Peru forearc area includes long-term uplift along the coastal plain and long-term subsidence along the continental margin, the neutral line being located within the $10 \mathrm{~km}$ seaward from the Present coastline. An extensive sequence of raised marine cliffs and associated notches evidences that the most recent uplift step (20-23 ka to Present) along the Cabo Blanco segment is related to a sequence of major earthquakes. We infer that eustacy exerts important feedback coupling to the seismogenic behavior of the North Peru subduction zone. We speculate that during sea level fall, pore fluid pressure diminishes along the subduction channel inducing a possible seaward migration of the locked zone (i.e., migration of the updip limit) reaching a maximum by the end of the eustatic low stand. During eustatic sea level rise, pore fluid pressure increases along the subduction channel. This in turn is capable of weakening the previously locked zone along the plate interface beginning an earthquake sequence. Earth's orbital variations are a potential external cause that may control the physical processes at work along plate interface.

Citation: Bourgois, J., F. Bigot-Cormier, D. Bourles, R. Braucher, O. Dauteuil, C. Witt, and F. Michaud (2007), Tectonic record of strain buildup and abrupt coseismic stress release across the northwestern Peru coastal plain, shelf, and continental slope during the past 200 kyr, J. Geophys. Res., 112, B04104, doi:10.1029/2006JB004491.

\footnotetext{
${ }^{1}$ Géosciences Azur, UMR 6526, Centre National de la Recherche Scientifique and Institut de Recherche pour le Développement, Université de Paris 6, Paris Cedex 5, France.

${ }^{2}$ Géosciences Azur, UMR 6526, Université de Nice, Nice Cedex 02, France.

Copyright 2007 by the American Geophysical Union. 0148-0227/07/2006JB004491\$09.00
}

\footnotetext{
${ }^{3}$ Centre Européen de Recherche et d'Enseignement des Géosciences de l'Environnement, Université Aix-Marseille III, Europôle Méditerranéen de l'Arbois, Aix-en-Provence Cedex 04, France.

${ }^{4}$ Géosciences Rennes, Université de Rennes1, Rennes Cedex, France.

${ }^{5}$ Géosciences Azur, UMR 6526, Observatoire Océanologique de Villefranche-sur-Mer, Villefranche-sur-Mer Cedex, France.
} 


\section{Introduction}

[2] The Peru subduction zone extends along the western margin of South America for $\sim 2000 \mathrm{~km}$ and accommodates the $\sim 8 \mathrm{~cm} \mathrm{yr}^{-1}$ E-W trending convergence of the Nazca plate with the South America plate (Figure 1). South of $2^{\circ} \mathrm{S}$, the Peru segment is characterized by a nearly horizontal subduction [Pilger, 1981]. Off northern Peru, between $3^{\circ} 30^{\prime}$ and $7^{\circ} 30^{\prime} \mathrm{S}$, the continental margin is characterized by the absence of contractile structures [Bourgois et al., 1988, 1993]. Extensional features extend not only throughout the middle and upper slopes but also along the lower slope. These extensional features appear to result from the downslope forces imparted by gravity as the continental margin oversteepened. Seaward dipping low-angle $\left(20^{\circ}\right.$ to $\left.30^{\circ}\right)$ detachments deep rooted in the continental basement of the margin were identified [Bourgois et al., 1988; von Huene et al., 1989], suggesting tectonic conditions that require considerable decoupling along the subduction zone and active subsidence of the continental margin [Scholl et al., 1980; Hussong and Wipperman, 1981; Aubouin et al., 1982, 1984; von Huene and Scholl, 1991; Clift et al., 2003; Vannucchi et al., 2003], a feedback process of subduction erosion working at depth [Scholl et al., 1980; von Huene et al.,1989; Ranero and von Huene, 2000; von Huene and Ranero, 2003; Hampel et al., 2004]. Subduction erosion is associated with mass removal from the upper plate at subduction zones that results in the extension and subsidence of the forearc. Subducted sediment along with fragmented material from the overriding plate accompanying the movement of the lower plate is a major process affecting rock and fluid dynamics at erosional convergent margin. This tectonic mode requires low coupling along the subduction channel allowing the fragmented material transferred toward the mantle [Shreve and Cloos, 1986; Wang and $H u, 2006]$.

[3] Along the studied segment of the Peru subduction zone, much of the coastal plain exhibits extensive raised marine terraces, locally known as tablazos. DeVries [1988] proposed an early Pleistocene age for the main tablazo, the so-called Mancora Tablazo. During the Pliocene and the Pleistocene times, the coastal plain of northwestern Peru was inundated to the Andean foothills. At that time, the Pacific coast was located landward at more than $35-100 \mathrm{~km}$ from the Present shoreline. Continued uplift of the Peruvian coastal plain caused the abandonment of embayment and inland seas. As opposed to the offshore segment of the margin, the uplift and related extensive emersion of the coastal shelf require high coupling along the plate interface and/or underplating at depth. Indeed, this segment exhibits a low level of seismic activity, suggesting that the seismogenic zone is strongly locked today [Gagnon et al., 2005]. This is in good agreement with the seismic gap identified to exist along the Peru-Chile trench, from $1^{\circ} \mathrm{N}$ to $8^{\circ} \mathrm{S}[$ Lay et al., 1982].

[4] This report explores the tectonic evolution of an onshore-offshore forearc transect located between $3^{\circ} 30^{\prime}$ and $7^{\circ} 30^{\prime} \mathrm{S}$. The geological and geophysical data collected from the coastal plain to the trench axis document a pervasive tectonic segmentation for the past 200-kyr evolution. Two tectonic segments exist along the coastal plain area. From north to south, it includes the uplifted Cabo

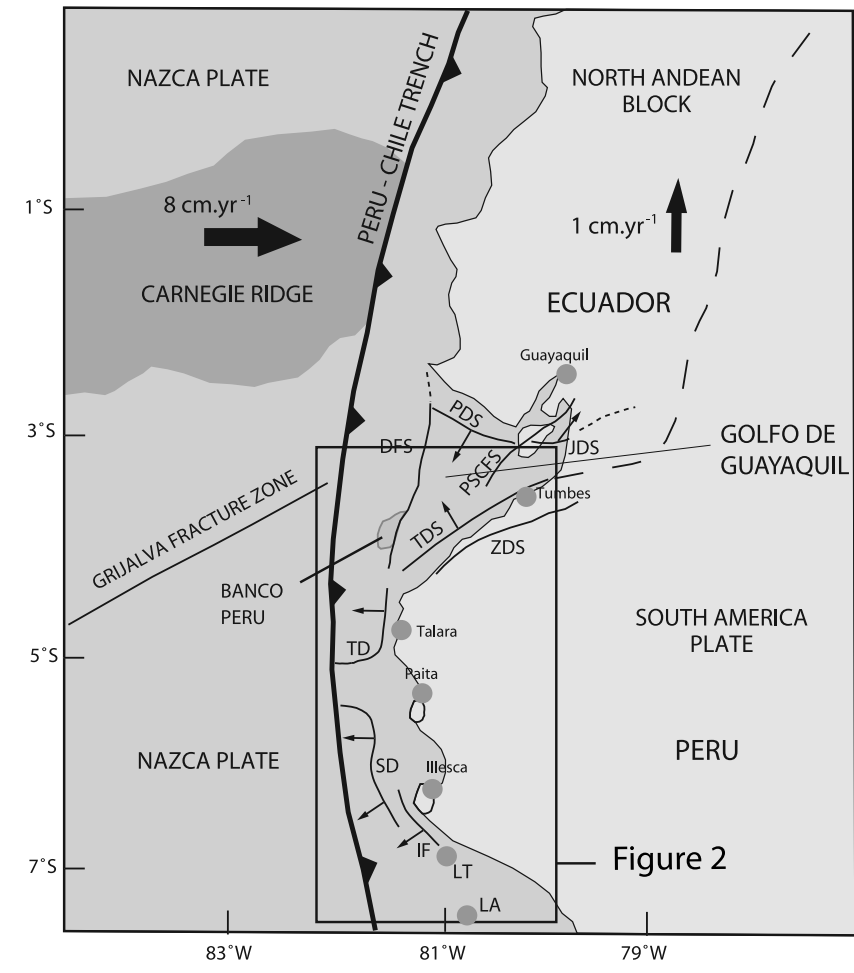

Figure 1. Location map of the studied area. Black lines with thin arrows, detachment; dash line, proposed eastern boundary of the North Andean block that migrates $\sim 1 \mathrm{~cm} \mathrm{yr}^{-1}$ to the north [Trenkamp et al., 2002]. DFS, Domitos fault system; IF, Illesca fault; JDS, Jambeli detachment system; LA, Isla Lobos de Afuera; LT, Isla Lobos de Tierra; PDS, Porsoja detachment system; PSCFS, Puna Santa Clara fault system; SD, Sechura detachment system; TD, Talara detachment system; TDS, Tumbes detachment system; ZDS, Zorritos detachment system.

Blanco and Paita-Illesca segments (Figure 2). The major detachment faults, which control the subsidence along the continental margin, also document a structural segmentation including the Talara, Paita, and Sechura segments (Figure 2) from north to south. The reconstructed uplift and subsidence history of the studied area allows us to investigate plate boundary processes including the following: (1) the control of the forearc tectonics, strain buildup, and segmentation by the subduction zone behavior at the timescale of the glacialinterglacial cycles; (2) the distribution of permanent deformation along the forearc area including long-term growth of coastal topography, uplift rate, and major earthquake recurrence; and (3) the eustacy feedback coupling to seismogenic behavior of the subduction zone.

\section{Geologic Framework}

\subsection{Onshore Geology}

[5] The Amotapes massif (Figure 2) consists of low-grade to high-grade metamorphic rock of Paleozoic age intruded by Mesozoic plutons [Travis et al., 1976] that extends southward to the Paita and Illesca areas. Cretaceous sediment unconformably overlies the basement rock. To the southeast of the coastal range is the Sechura basin extending 
from $4^{\circ} 30^{\prime}$ to $7^{\circ} \mathrm{S}$. It consists of $\sim 3000 \mathrm{~m}$ of upper slope and shelf sediments, which accumulated during the past $40 \mathrm{Myr}$. To the west of the Amotapes massif is the Talara basin. It consists of $\sim 12,000$-m-thick accumulation of Cretaceous, Paleocene, and Eocene sediments. The upper Oligocene to Miocene sequences of the Sechura basin [Caldas et al., 1980] do not extend to the north into the Talara basin. To the north of the Talara basin, the Zorritos-Tumbes basin (ZTB, Figure 2) exhibits thick accumulation of Oligocene and Miocene coastal sediments, which are exposed along the southern coastal edge of the Golfo de Guayaquil basin (i.e., the ZTB). The Amotapes-Illesca continental basement high has a seaward extension to the south in the Isla Lobos de Tierra (LT, Figure 2). It was described [Thornburg and Kulm,

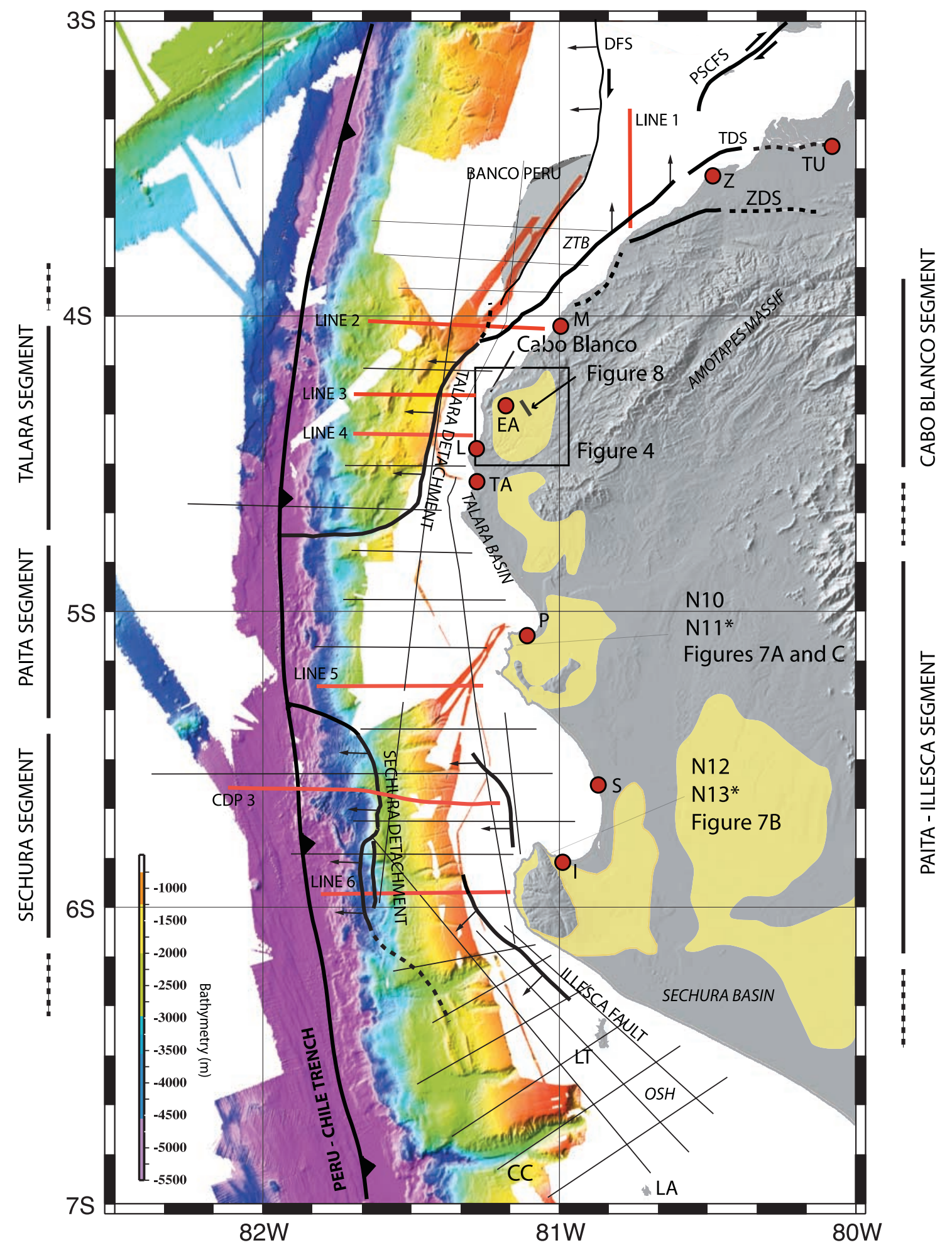

Figure 2 

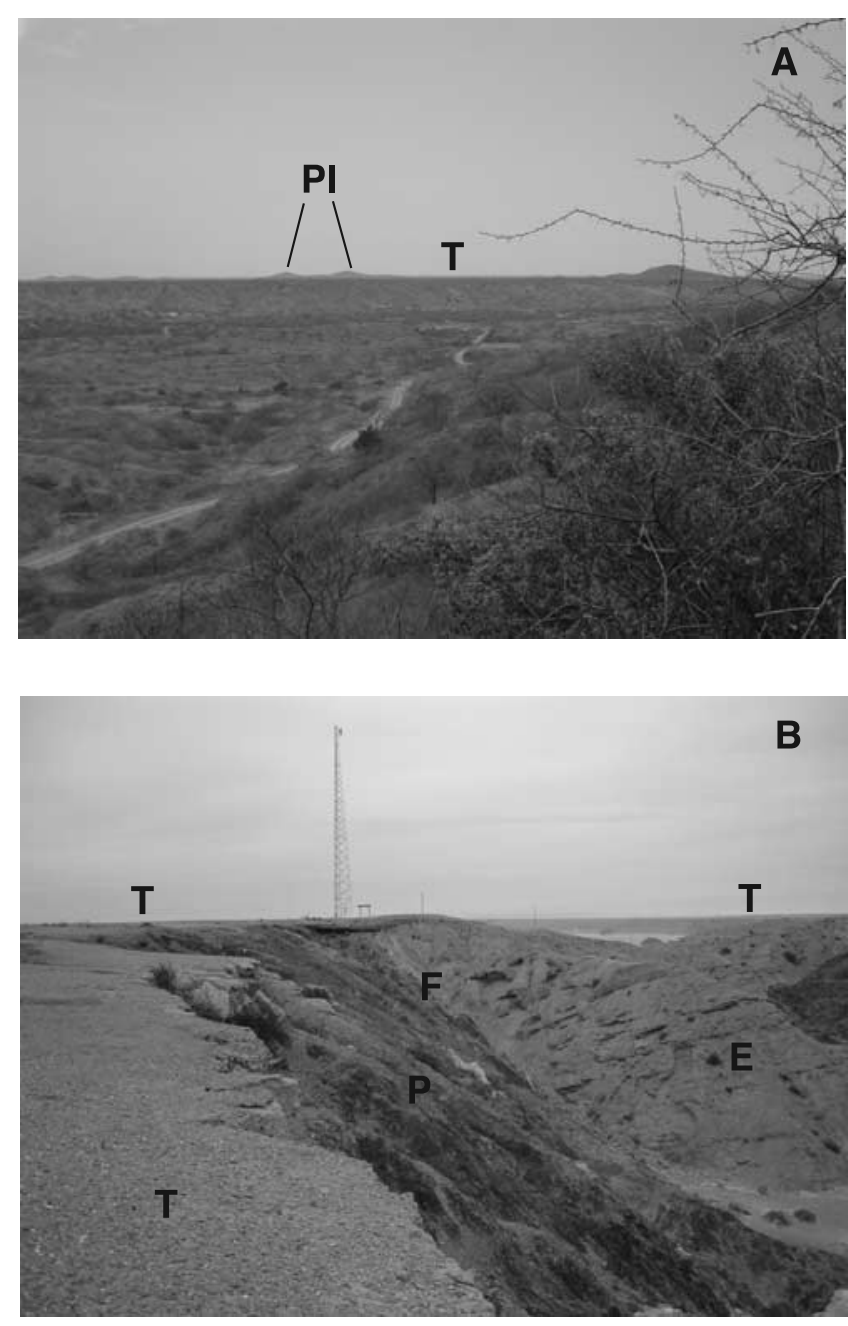

Figure 3. The tablazos of the coastal area of northern Peru. (a) The Mancora tablazo east of El Alto. Photo taken looking towards the north. (b) The Talara tablazo in the Paita area. Note that the major normal fault between the Eocene of the Talara Formation and the Paleozoic basement predates the tablazo. Photo taken looking towards the northwest. E, Eocene sandstone of the Talara Formation; F, Fault; P, Paleozoic metamorphic basement; Pl, paleo-island; T, tablazo. See text for more details.
1981] as the outer-shelf structural high (OSH, Figure 2). It trends parallel to the Trench axis and forms the western flank of the seaward prolongation of the Sechura basin [Thornburg and Kulm, 1981; Kulm et al., 1981, 1988].

\subsection{Tablazos}

[6] In the surveyed area, between $3^{\circ} 30^{\prime}$ and $7^{\circ} 30^{\prime} \mathrm{S}$, the tablazos (Figure 3) of Pliocene to Quaternary age cover $\sim 20,000 \mathrm{~km}^{2}$ from $3^{\circ} 50^{\prime}$ to $6^{\circ} 30^{\prime} \mathrm{S}$. Four terraces including the Mancora, Talara, Lobitos tablazos, and the Salina plains were discussed [Bosworth, 1922]. Subsequently, DeVries [1984, 1988] accepted the proposed division for tablazos. He noted that deep valleys including Quebrada Honda, Quebrada Pariñas, and the Rio Chira from north to south interrupt the tablazos. On the basis of sedimentologic, paleontologic, and stratigraphic data, he described the Taime Formation in an area located south of El Alto (EA, Figure 2). Previously interpreted [Olson, 1932] as part of the Mancora tablazo, the Taime Formation [DeVries, 1988] was subsequently divided into three members: the Carrizo, Golf Course, and El Nuro Members from base to top. A Pliocene to Pleistocene age for the Taime Formation was proposed. This age based on mollusk fauna associations is speculative since most of them are extant. Also, mollusks, in general, are not good marker of geologic time because they tend to follow water temperature.

\subsection{Offshore Geology}

[7] The Andean margin off Peru consists of continental crust against which a small accretionary complex accumulated during late Neogene [von Huene et al.,1988; Suess et al., 1988]. To the north, along seismic record CDP3 (Figure 2), SeaBeam bathymetry and additional multichannel seismic records revealed mass wasting in the form of avalanche debris [Bourgois et al., 1988; von Huene et al., 1989] along the lower slope and trench. The late Pleistocene tectonic history of this area is as follows [Bourgois et al., 1993]: During the past $400 \mathrm{ka}$, a broad rollover fold formed along the middle slope area, in association with a major seaward dipping detachment fault. The previously mentioned catastrophic debris avalanche occurred as the result of oversteepening of the seaward flank of the rollover fold. The Hydrosweep (R/V Sonne cruise 78, March-April 1992) and SeaBeam (Seaperc cruise of the R/V Jean Charcot, July 1986) surveys of the Peru-Chile trench off northern Peru allowed to constrain the age of the gravity failure of the slope at $13-16 \mathrm{ka}$, producing a destructive tsunami [von Huene et al., 1989]. To the north, the complexity of the

Figure 2. Area of study showing the data considered in this work. (1) The tablazos (light yellow) along the coastal plain of northern Peru. Location of samples N10 to N13 is shown. Location of samples N01 to N07 (Figure 4). Onshore topography from ftp://eOmss21u.ecs.nasa.gov/srtm/. (2) The red lines 1 to 6 and CDP3 show the seismic profiles of Figures 13, 14, and 15 and the profile recorded during the Nazca Plate project [Sheperd and Moberly, 1981], respectively. The thin black line shows the seismic profiles analyzed to map the major detachments and faults (solid black line with thin arrow). Thick black line with barb shows the decollement. The EM12 bathymetry of the middle and lower continental slopes, the trench, and the subducting Nazca plate was acquired during the ANDINAUT cruise (J. Bourgois, chief scientist). CC, Chiclayo canyon; DFS, Domitos fault system; EA, El Alto; I, Illesca; L, Lobitos; LA, Isla Lobos de Afuera; LT, Isla Lobos de Tierra; M, Mancora; OSH, outer-shelf structural high [Thornburg and Kulm, 1981]; P, Paita; PSCFS, Puna Santa Clara fault system; S, Sechura; TA, Talara; TDS, Tumbes detachment system; TU, Tumbes; Z, Zorritos; ZDS, Zorritos detachment system; ZTB, Zorritos-Tumbes basin; asterisk denotes reference sample. Location of the surveyed area in Figure 1. Location of Figures 4, 7a, 7b, 7c, and 8 is shown. 


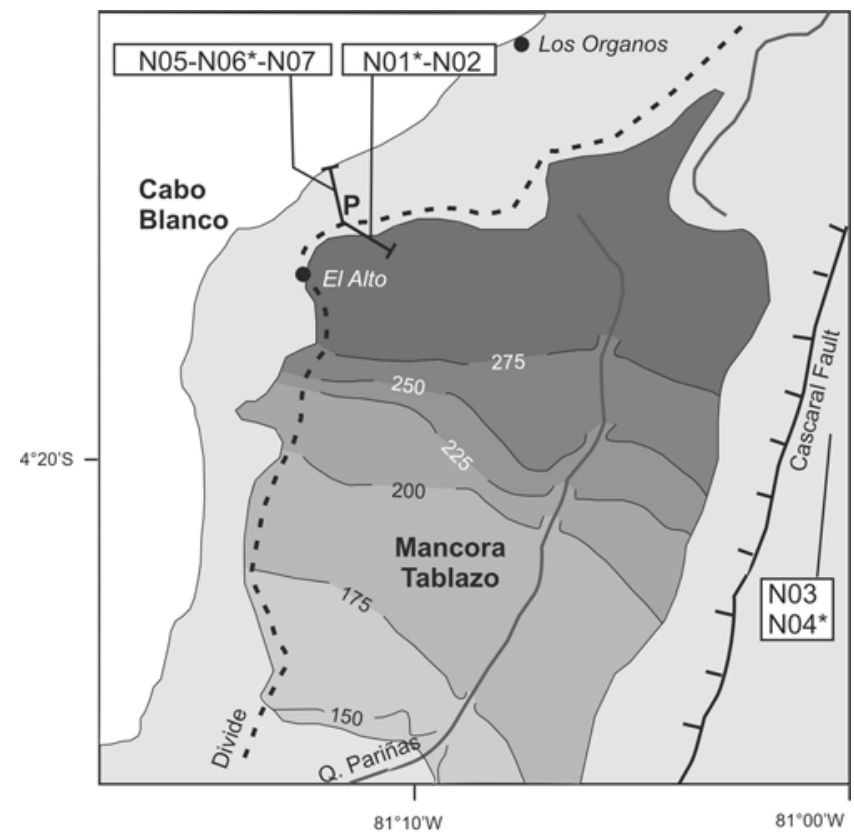

Figure 4. Map of the Cabo Blanco area showing the flat Mancora tablazo dipping to the south from $\sim 280$ (El Alto area) to $\sim 150 \mathrm{~m}$ amsl. Contour interval is $25 \mathrm{~m}$. Line with barbs shows the Cascajal normal fault (downthrow side to the west). P, profile of Figure 9 (see text for description). N01 to N07, sample location; asterisk denotes reference sample. Location is shown in Figure 2. See text for more details.

subsurface structure identified from oil well data allowed Sheperd and Moberly [1981] to identify a major detachment fault system located off Talara, south of Cabo Blanco. Therefore, detachment faulting has been characterized for a long time as a major tectonic process shaping actively the northern Peru margin.

[8] To the south, along the Chiclayo canyon $\left(7^{\circ} \mathrm{S}\right)$, the Andean metamorphic basement extends seaward to a site located $19 \mathrm{~km}$ landward from the trench axis [Sosson et al., 1994]. At 2400-m water depth, Pliocene mudstones unconformably overlying the metamorphic basement were sampled during the Nautiperc cruise of the submersible Nautile (March-April 1991). This main subaerial unconformity, which extends across the margin from the upper slope to the lower middle slope boundary, allowed for the reconstructing the subsidence history of the northern Peru margin at two sites. The rates of subsidence of the middle and upper slope areas are 713 and $452 \mathrm{~m} \mathrm{Ma}^{-1}$ during the past $5.1-$ 5.3 Myr, respectively, that is in good agreement with the extensional tectonic regime identified along the continental margin to the north. The solid material removed by subduction erosion along this transect was calculated to be between $\sim 25$ and $100 \mathrm{~km}^{3} \mathrm{Myr} \mathrm{km}^{-1}$ for the past 5.1-5.3 Myr.

\section{Onshore Data}

\subsection{Sampled Geomorphic Markers}

[9] Samples N03 to N07 (Figure 4) were collected along associated breaking-wave geomorphologic features in the
El Alto-Cabo Blanco area. These geomorphologic records (Figures $5 \mathrm{a}$ and $5 \mathrm{~b}$ ) sculptured by marine erosion exhibit a typical profile that includes the following: (1) a short seaward sloping platform covered by shingle or beach material mainly composed of well-rounded and sorted gravel (bg, Figure 5); (2) a wave-cut notch (n, Figure 5), which developed at the base of a cliff indicating breakingwave active erosion when formed; (3) a subvertical cliff (cl, Figure 5) associated with rockfall (rf, Figure 5b); and (4) a cap (c, Figure 5) of casehardened sandstone [Sunamura, 1992]. Due to the dry and stable climatic conditions prevailing in the coastal fringe of Peru [DeVries et al., 1997] since at least the middle Miocene [Alpers and Brimhall, 1988; Hoke et al., 2004], these coastal landforms
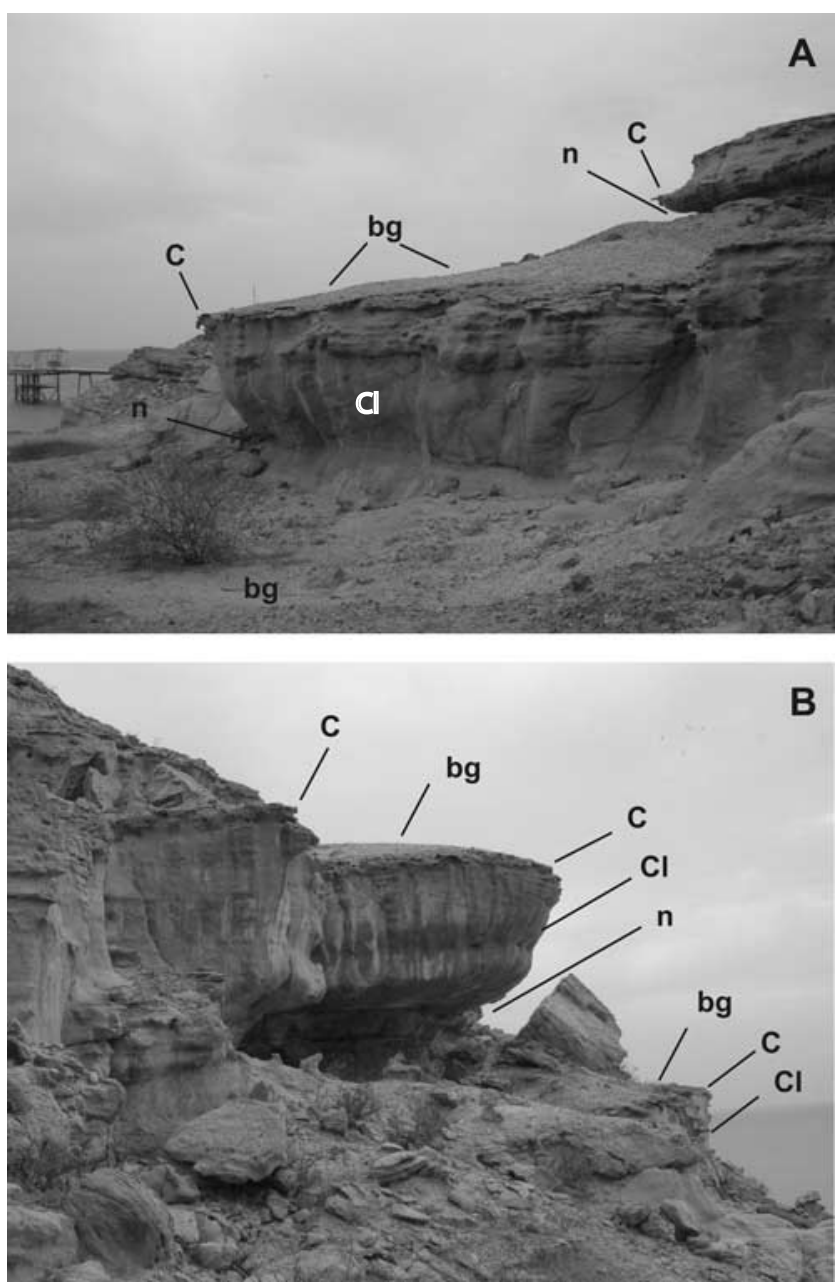

Figure 5. Uplifted coastal landforms investigated along profile $\mathrm{P}$ at Cabo Blanco (location of profile on Figure 4). (a) The estimated coseismic uplift between notches is $\sim 6 \mathrm{~m}$. Note that the Eocene sandstone of the Talara Formation is gently dipping to the right. Photo taken looking towards the north. (b) The estimated coseismic uplift between notches at that site is $\sim 9 \mathrm{~m}$ (the cliff hides the upper notch from view). Photo taken looking towards the west. bg, Well-rounded beach gravel along erosional surf bench (i.e., short seaward sloping platform); c, cap of casehardened sandstone; cl, subvertical abandoned cliff; n, wave-cut notch. See text for more details. 

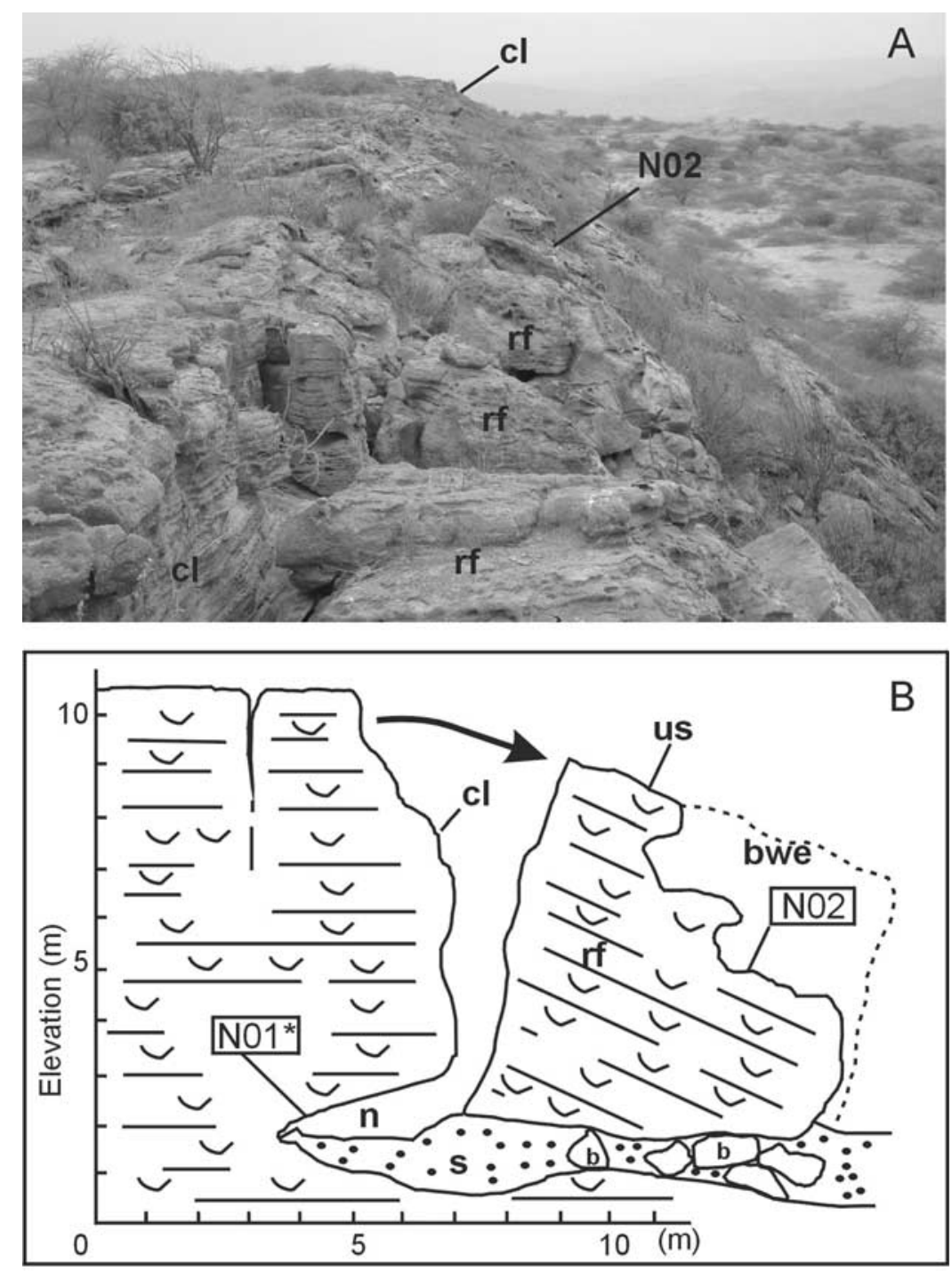

Figure 6. (a) Paleo-shore line extending for kilometers along the same contour line. Photo taken to the north. Location of samples N01 and N02 is shown in Figure 4. The beach-rock facies (i.e., El Nuro Member of the Taime Formation) exposed along the cliff is $\sim 160 \pm 12 \mathrm{ka}$ in age (age of the El Nuro Member, see Figure 8). The cliff age (i.e., the age at which the cliff developed) is $61.4 \pm 7.2 \mathrm{ka}$ (i.e., the ${ }^{10} \mathrm{Be}$ age of sample N02). bwe, Breaking wave erosion (i.e., loosening fragments of rock); cl, cliff; $\mathrm{n}$, notch; rf, rock fall; s, sand; us, upper side of block; asterisk denotes reference sample. See text for more details.

are particularly well preserved. The local coastal landform substrate is composed of Eocene porous sandstone (i.e., the Talara Formation) particularly liable to coating processes. Cement formed by evaporation of mineral-bearing solutions including salty marine water from below made the cap sandstone (c, Figure 6) stronger and less ready to erosion than the surrounding geomorphologic features when they evolved. Because the upper side of the cap is also well exposed to cosmic ray, samples N03, N05, and N07 were collected from caps for in situ ${ }^{10} \mathrm{Be}$ analysis.

[10] Samples N01 and N02 are from a cliff, which exhibits detached rotated blocks underlying a paleo-rocky coast (Figures 6a and 6b) as it was when it evolved including a deeply incised notch. The sampled detached block exhibits strong breaking-wave erosion. The seaward side of the block is deeply hollowed out evidencing mechanical abrasion from wave-carried beach sediment. This side of the block exhibits exceptionally well-preserved grooves and heavy spray structures indicating that breaking-wave erosion features have suffered low erosion rate since exposure to wave attack. Moreover, the upper side (us, Figure 6b) of the block shows well-preserved sedimentary structures such as prediagenetic mud crack and bird footprint indicative of exceptionally low rate of erosion since they formed. Consequently, we infer that breaking-wave erosion features of the sampled block have suffered low erosion rate since exposure to cosmic rays whose minimum duration is thus calculated to be $61.4 \pm 7.2 \mathrm{kyr}$.

[11] Samples N10 to N13 (Figures 7a, 7b, and 7c) were taken from the top surface of in situ quartz veins that 

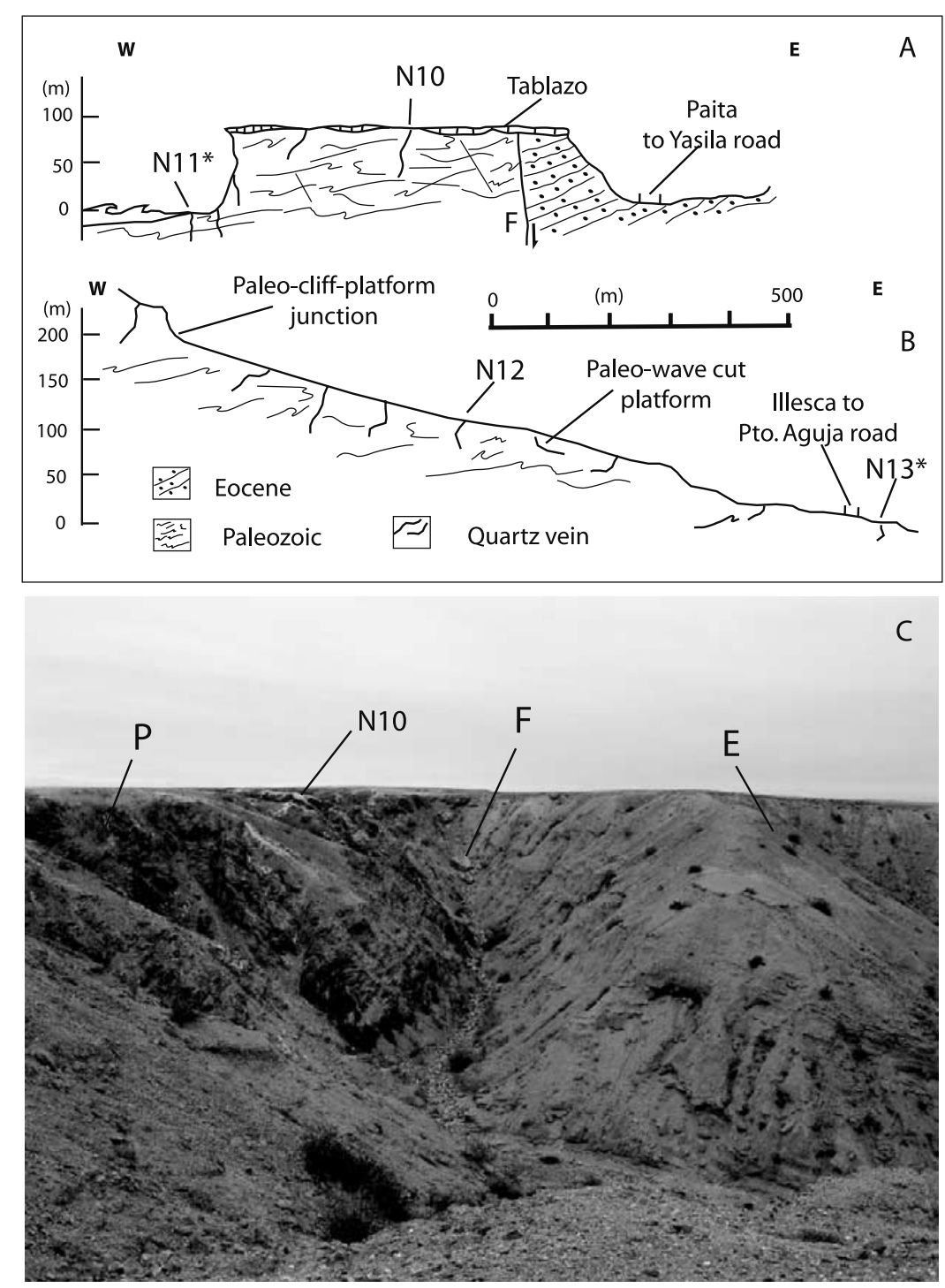

Figure 7. Geological sections at Paita (a) and Illesca (b) areas. The N11* and N13* reference samples were collected at less than $15 \mathrm{~m}$ from the toe of the Present sea cliff along the wave-cut platform and inside an 8- to 10-m-deep canyon, respectively. (c) The N10 sample was collected from a quartz vein, which is exposed between thin patches of the Talara tablazo. E, Eocene of the Talara Formation; F, pretablazo normal fault; N10 to N13, sample sites; P, black schist of Paleozoic age. See text for more details.

intruded Paleozoic black schist cropping out along erosional surf benches. The quartz vein projects only few centimeters above the local surface of the surrounding schist, suggesting that low denudation prevailed since exposure. We assume that a high rate of denudation applied to those sites would result in creating quartz ridge rising high above the black schist much more easily prone to erosion. To summarize, since formation, the exposed surfaces of sampled sites have not been subjected to significant erosion.

\subsection{Analytical Procedure}

[12] Cosmic ray exposure dating, based on the accumulation of nuclides produced through nuclear reactions induced by high-energy cosmic radiation, is now commonly used in geomorphologic studies. In this paper, we use in situ produced ${ }^{10} \mathrm{Be}$ to date the exposure of morphological markers [Lal, 1991a, 1991b]. Our sampling selection strategy minimizes the effects of exposure prior to exposition and of erosion following formation. Eleven samples (Table 1) have been collected from key sites. Quartz was isolated and purified from the atmospheric ${ }^{10} \mathrm{Be}$ following the standard method [Brown et al., 1992]. After dissolution in Suprapur HF, the resulting solution was spiked with $300 \mu \mathrm{g}$ of ${ }^{9}$ Be carrier. Beryllium was extracted [Brown et al., 1992; Bourles, 1988], and cosmogenic ${ }^{10} \mathrm{Be}$ measurements were performed with the AMS Tandetron facility (Gif-sur-Yvette, France) [Raisbeck et al., 1987, 1994]. Measured ratios $\left({ }^{10} \mathrm{Be} /{ }^{9} \mathrm{Be}\right)$ were calibrated directly against the National Institute of Standards and Technology (NIST) standard reference material SRM 4325 using its certified ${ }^{10} \mathrm{Be} /{ }^{9} \mathrm{Be}$ ratio of $(26.8 \pm 1.4) \times 10^{-12} \cdot{ }^{10} \mathrm{Be}$ uncertainties were calculated by associating an estimate of $3 \%$ instrumental 
Table 1. Minimum Cosmic Ray Exposure Ages Calculated From in Situ Produced ${ }^{10}$ Be Concentrations Within Morphological Markers

\begin{tabular}{|c|c|c|c|c|c|c|c|c|c|}
\hline Sample & Latitude, ${ }^{\circ} \mathrm{S}$ & Longitude, ${ }^{\circ} \mathrm{W}$ & $\begin{array}{c}\text { Altitude, } \\
\mathrm{m}\end{array}$ & $\begin{array}{c}\text { Depth, } \\
\mathrm{cm}\end{array}$ & $\begin{array}{c}\text { Production, } \\
\text { at } / \mathrm{g} / \mathrm{yr}^{(1)}\end{array}$ & ${ }^{10} \mathrm{Be}$, at $/ \mathrm{g}$ & ${ }^{10} \mathrm{Be}$ error, at $/ \mathrm{g}$ & Tmin, ka & $\pm 1 \sigma, \mathrm{ka}$ \\
\hline N02 & $4^{\circ} 13.98$ & $81^{\circ} 10.57$ & 296 & $0-5$ & 4.28 & 204275 & 20677 & 61.413 & 7.226 \\
\hline $\mathrm{N} 01^{\mathrm{a}}$ & $4^{\circ} 13.98$ & $81^{\circ} 10.57$ & 293 & 700 & 4.28 & 54878 & 15927 & & \\
\hline N03 & $4^{\circ} 19.93$ & $81^{\circ} 00.53$ & 342 & $0-5$ & 4.44 & 39966 & 9017 & 18.241 & 3.848 \\
\hline $\mathrm{N} 4^{\mathrm{a}}$ & $4^{\circ} 19.92$ & $81^{\circ} 00.41$ & 362 & 800 & 4.50 & 40684 & 28793 & & \\
\hline N05 & $4^{\circ} 13.73$ & $81^{\circ} 12.23$ & 50 & $0-5$ & 3.46 & 20985 & 4518 & 8.096 & 1.810 \\
\hline N07 & $4^{\circ} 13.85$ & $81^{\circ} 12.28$ & 94 & $0-5$ & 3.70 & 67979 & 6970 & 20.362 & 2.419 \\
\hline $\mathrm{N}^{0} 6^{\mathrm{a}}$ & $4^{\circ} 13.67$ & $81^{\circ} 12.19$ & 24 & 700 & 3.51 & 7007 & 1821 & & \\
\hline N10 & $5^{\circ} 08.41$ & $81^{\circ} 10.46$ & 82 & $0-5$ & 3.65 & 481866 & 34358 & 141.334 & 13.171 \\
\hline $\mathrm{N} 11^{\mathrm{a}}$ & $5^{\circ} 08.73$ & $81^{\circ} 10.41$ & 0 & $0-5$ & 3.43 & 17522 & 3953 & 5.114 & 1.194 \\
\hline N12 & $5^{\circ} 48.48$ & $81^{\circ} 03.12$ & 116 & $0-5$ & 3.73 & 591667 & 34192 & 164.544 & 13.707 \\
\hline $\mathrm{N} 13^{\mathrm{a}}$ & $5^{\circ} 48.26$ & $81^{\circ} 02.95$ & 10 & 1000 & 3.45 & 20510 & 4745 & 5.953 & 1.423 \\
\hline
\end{tabular}

${ }^{\text {a}}$ Reference sample collected at depth greater than $500 \mathrm{~cm}$. See text and Figure 7 for samples N11 and N13. For laboratory methods, see text for more details.

uncertainty with $1 \sigma$ uncertainties associated with counting statistics, blank correction $\left({ }^{10} \mathrm{Be} /{ }^{9} \mathrm{Be}=5.654 \times 10^{-15}\right)$ [Raisbeck et al., 1994; Middleton et al., 1993], and 6\% in production rate estimates [Stone, 2000]. To minimize the influence of inherited cosmogenic, we measured ${ }^{10} \mathrm{Be}$ concentrations in reference samples (Table 1) collected at a depth where the production is only due to muons [Braucher et al., 2003] since the last exposure to cosmic rays. To date the surface, we subtract these concentrations to those of surficial samples collected at the same place. Because the concentration of cosmogenic nuclides depends on both exposure time span and erosion rate, exposure ages can be obtained only if erosion rate is known or can be neglected.

\subsection{Erosion Rate}

[13] In the surveyed area, the Atacama Desert extends to the north of the studied area, at about $3^{\circ} 30^{\prime} \mathrm{S}$. Several studies suggest that extremely arid conditions in the western Andes and forearc were established between 10 and $14 \mathrm{Ma}$ [Alpers and Brimhall, 1988; Hoke et al., 2004]. The aridity of this desert which is considered as one of the driest worldwide is generally assumed to have started with the onset of the Peru upwelling in the SW Pacific at that time

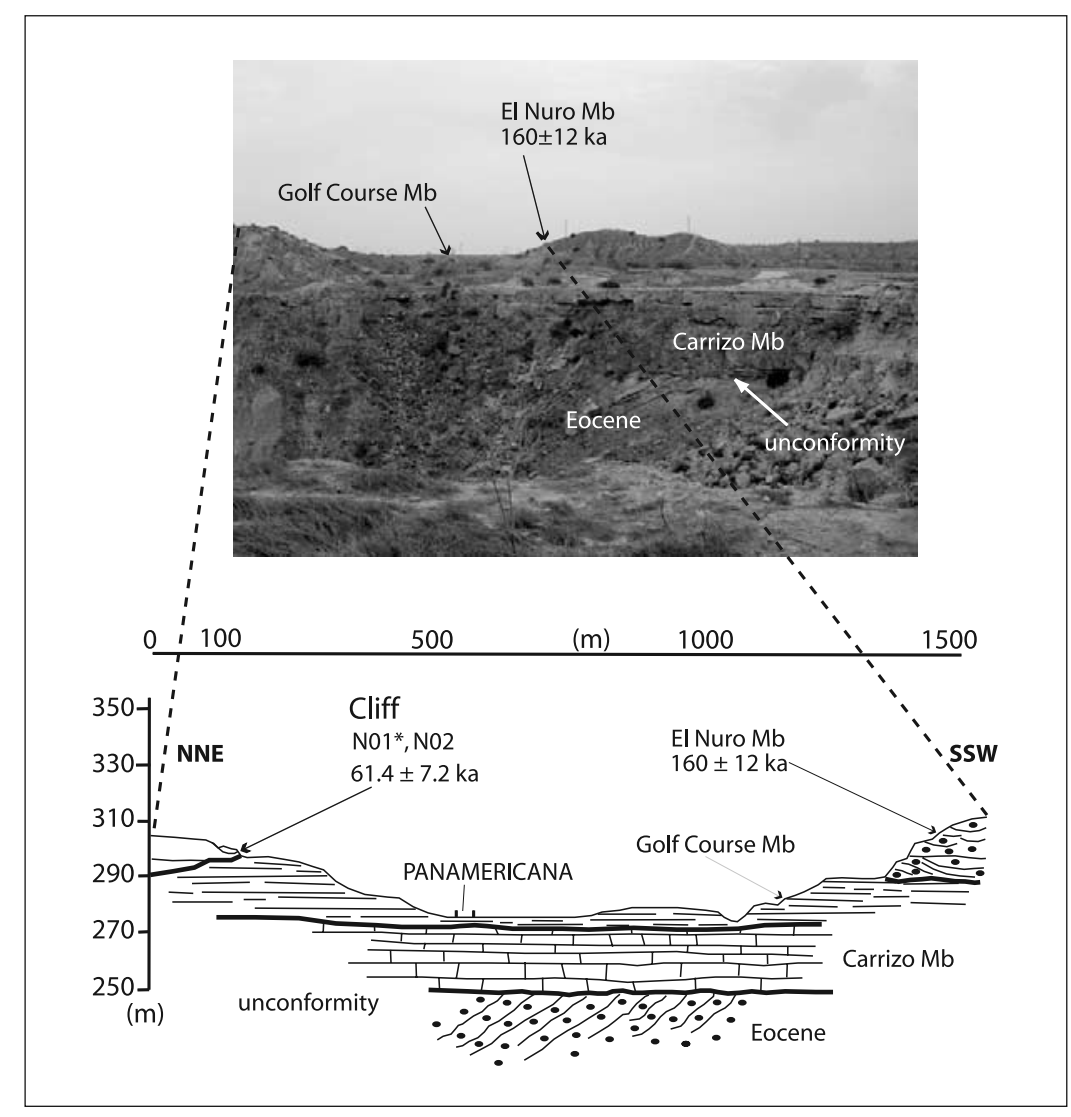

Figure 8. Geological section of the Taime Formation showing the Carrizo, Golf Course, and El Nuro Members from base to top. The cliff located on the left is shown in Figure 6a. The Taime Formation, which is strictly horizontal unconformably overlies the Talara Formation of Eocene age; asterisk denotes reference sample. Location of profile is shown in Figure 2. See text for more details. 


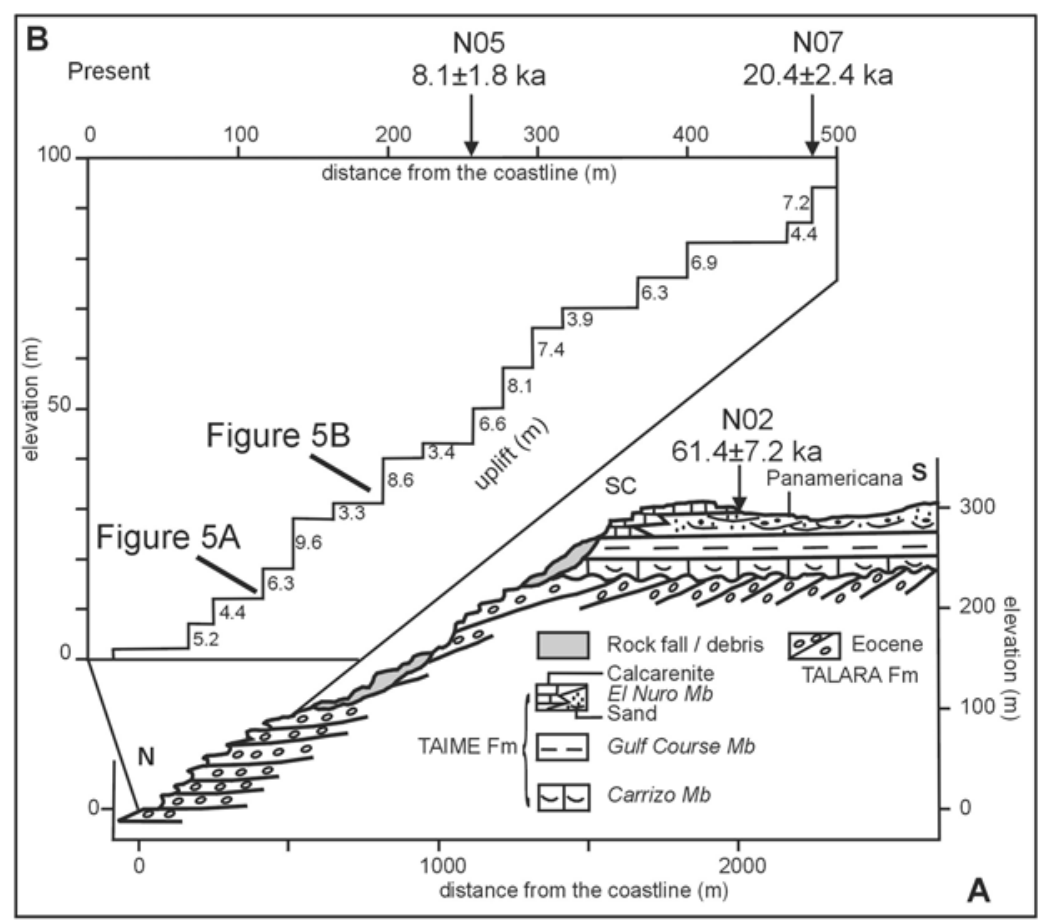

Figure 9. (a) Transect from the Mancora tablazo to the coastline across the divide. Note the steep and rough geomorphic signature west of the divide. Location of profile, $P$, is shown in Figure 4. (B) Elevation versus distance from the coastline diagram of coseismic terraces identified along the Cabo Blanco transect between 0 - and $\sim 100-\mathrm{m}$ elevation. sc, Seaward cliff; Panamericana, Panamericana road. Note that this sc cliff connects to the cliff where N02 sample was collected. See text for more details.

and have prevailed ever since. Although proposals have been made for rates ranging from 4 to $5 \mathrm{~m} \mathrm{Myr}^{-1}$ surface lowering rates in arid areas [Matmon et al., 2005; Brown et al., 2000; Cockburn et al., 2000], tests of them remain few. However, these high lowering rates are not compatible with the apparent freshness of landform under arid conditions as exposed in the surveyed area. An accurate study of the landscape evolution of the hyperarid central Namib sector [Van der Wateren and Dunai, 2001] indicates that denudation rates since at least $10-15$ Ma have been significantly lower (i.e., lower than 0.11 to $0.15 \mathrm{~m} \mathrm{my}^{-1}$ ). These low rates are in good agreement with the virtually unweathered landform (i.e., not significantly affected by erosion) selected in this present work for measurements. The two highest ${ }^{10} \mathrm{Be}$ concentrations measured for samples N10 to N13 (Table 1) yield to maximum steady-state erosion rates of $4.63 \pm 0.43$ and $3.76 \pm 0.31 \mathrm{~m} \mathrm{My}^{-1}$, respectively. As recently demonstrated by Dunai et al. [2005] with cosmogenic ${ }^{21} \mathrm{Ne}$ measurements in sediments, erosion rate in the Atacama Desert area is probably much lower (i.e., close to those calculated for the Namib Desert) and therefore has been neglected in this study to calculate exposure ages based on in situ produced ${ }^{10} \mathrm{Be}$ concentrations.

\subsection{The Northern Cabo Blanco Segment}

3.4.1. Geology and Morphology

[14] The Cabo Blanco segment (Figures 2 and 4), north of $4^{\circ} 30^{\prime} \mathrm{S}$, exhibits the 60 - to $100-\mathrm{m}$-thick Taime Formation (Figure 8), which unconformably overlies the Eocene sandstone of the Talara Formation. It contains fine- to mediumgrained sand with horizons of gravel, shelly sandstone, balanid worm, and serpulid aggregate that accumulated in a shallow shelf environment. On the basis of optically stimulated luminescence (OSL) dating, an age of $160 \pm$ $12 \mathrm{ka}$ [Pedoja, 2003] was obtained for a well-sorted medium-grained sandstone of the upper part of the El Nuro Member (i.e., the upper member of the Taime Formation). At least part of the Cabo Blanco segment was meters to tens of meters below sea level during glacial oxygen isotope 6 (SPECMAP, Standard isotope curve, Imbrie et al., 1984) when eustatic sea level was 40 to $100 \mathrm{~m}$ below the Present mean sea level. Subsequently, the soft rock of the Taime Formation permitted the $\sim 1000-\mathrm{km}^{2}$ continuous flat surface of the Mancora Tablazo (Figures 3a and 4) to develop.

[15] A divide paralleling the shoreline [DeVries, 1984] at distances varying from 2 to $6-7 \mathrm{~km}$ (Figure 4) bounds the Mancora Tablazo to the west. To the west of the divide, the hillslope profile is steep and rough, extending to the coastline (Figure 9a). To the east of the divide, the Mancora Tablazo, which was a part of the Peru continental platform when developed, dips gently to the south from $\sim 280$ to $\sim 150 \mathrm{~m}$ above mean sea level (amsl hereafter) with a very low gradient of $0.65 \%$. The surface of the Mancora Tablazo exhibits parallel gravel ridges trending E-W [DeVries, 1984]. These ridges that extend for several kilometers are likely to record stillstand steps during short reoccupation [Kelsey and Bockheim, 1994]. Because the ridge material is coarsening eastward to conglomerate with less marine shell, we infer that gravel and conglomerate originated from the Amotape drainage system. The southward dip of the Mancora Tablazo, perpendicular to the abovementioned beach ridges, was associated with a southward tilt [Macharé and 
Ortlieb, 1994] of a tectonic block extending from Mancora to Quebrada Pariñas. Because the underlying Taime Formation is strictly horizontal (Figure 8) along strike, we assume that the dip of the Mancora Tablazo has no tectonic origin. The divide that limits the Mancora Tablazo to the west exhibits reef crest facies with coral heads and coralline crust associated with cemented calcarenite (Figure 9a) and high-energy facies including beach-rock material. These facies are part of the upper section of the El Nuro Member, which accumulated during the oxygen isotope 6 low stand (see above). The divide separated the windward rocky coast to the west from the back reef still-water zone (i.e., the Mancora Tablazo area) to the east where thin lagoon sediment accumulated. To the east, the Amotape river system provided detrital material. A shallow water fan accumulated east of the lagoon. We infer that the dissimilar morphological signature on either side of the divide originated from a paleogeographic inheritance.

[16] The calcarenite of the El Nuro Member dominates the landscape at about $300 \mathrm{~m}$ elevation in the El Alto area (sc, Figure 9a). Within these specific facies, erosion is dominated by detachment of massive boulders (i.e., rockfall and debris, Figures $6 \mathrm{a}$ and $6 \mathrm{~b}$ ) along a continuous cliff from west to east (i.e., from sc site on Figure 9 to the N02 sample site) following the 290-m contour. Because lithophagous borring is frequent along faces of detached boulders from the cliff, we assume that rockfall originated at least partly from breaking-wave erosion. In this area, two sudden relative sea level falls have left rocky coast cliffs and associated notches between 280 and $305 \mathrm{~m}$ amsl. Because the cliff at site N02 connects with the cliff located west of El Alto (i.e., sc, Figure 9a), we assume that these two sites evolved coevally at $61.4 \pm 7.2{ }^{10} \mathrm{Be}$ kyr (Table 1 and Figures 6, 8, and 9a), long after the El Nuro Member calcarenite accumulated.

[17] To the west of the divide (Figures 9a and 9b), an extensive sequence of raised marine cliffs and associated notches characterizes the seaward slope between $\sim 100$-m elevation and the shoreline. Because it occurred during the last deglacial sea level rise (Figure 9b and Table 1), these regressive terraces most likely evidence a sudden fall of relative sea level primarily caused by rapid tectonic uplift that, in addition, prevents their destruction by reoccupation (Figure 10). Indeed, historic reports of sudden uplift of strandlines during large earthquakes suggest that older strandlines may have been raised coseismically during recurrent earthquakes [Plafker, 1969; Thatcher, 1984; Lajoie, 1986; Berryman, 1987; Nelson and Manley, 1992; Ortlieb et al., 1996; Chappell et al., 1996; Peltzer et al., 1996; Reilinger, 2000; Lagabrielle et al., 2003; Ota and Yamaguchib, 2004; Taylor et al., 2005]. We surveyed these features using two TRIMBLE 4600 LS receivers. The vertical location of the notch is the main error source. We regard our field leveling as correct to within $\pm 0.5 \mathrm{~m}$. Between the shoreline and $100 \mathrm{~m}$ amsl, there are 16 fossil shorelines. They record uplifting tectonic events having amplitudes ranging from $\sim 2$ to $\sim 10 \mathrm{~m}$ (i.e., uplift between two following notches, Figure 5a). Because postseismic relaxation and sea level rise can lead to reoccupation of a shoreline, the estimated number of events is minimum. Two casehardened sandstone caps were sampled (N05 and N07, Figure 4) for in situ produced ${ }^{10} \mathrm{Be}$ analyses (Table 1). Assuming a

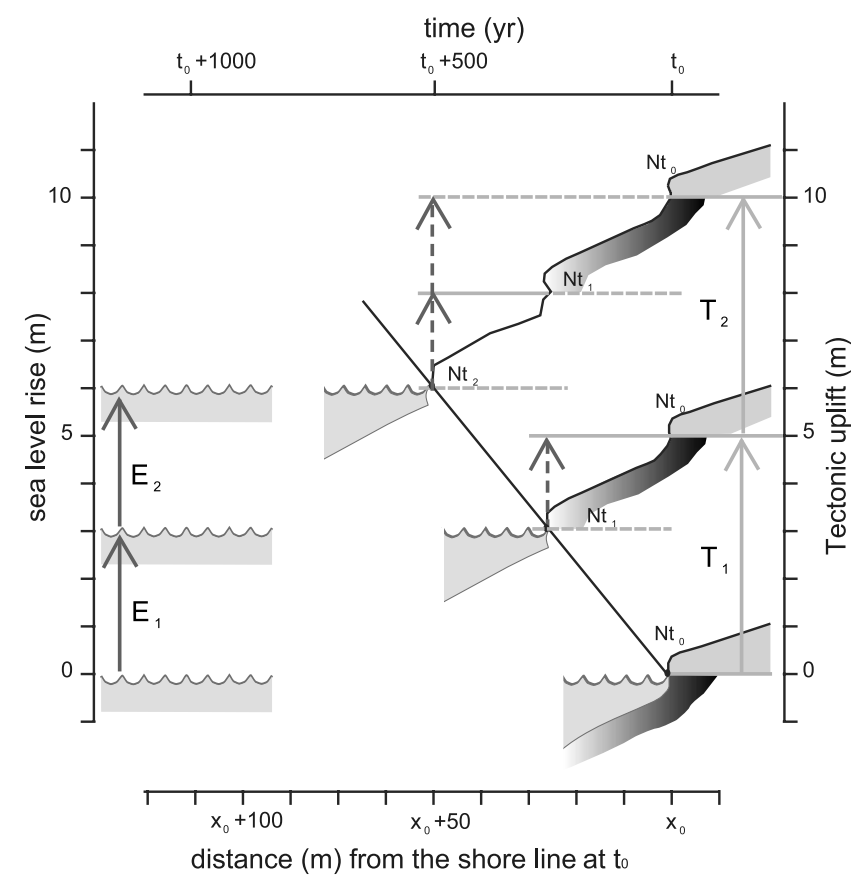

Figure 10. Reconstruction of relative sea level drop evolution allowing the stepped shoreline features observed at Cabo Blanco area to be preserved during eustatic sea level rise following the LGM. Two earthquake cycles are shown. The net tectonic uplift at the time of an earthquake (arrows $\mathrm{T}_{1}$ and $\mathrm{T}_{2}$ ) including preseismic, coseismic, and postseismic displacements is higher than the eustatic sea level rise (arrows $E_{1}$ and $E_{2}$ ), which occurs during the earthquake cycle (the time between two earthquakes). A net fall of relative sea level (dash arrow) accumulated during recurrent earthquakes. As a result, the shoreline migrates seaward. $\mathrm{Nt}_{0}, \mathrm{Nt}_{1}, \mathrm{Nt}_{2}$, notches at time $t_{0}, t_{1}$, and $t_{2}$, respectively. The 5-m tectonic uplift $(T)$, the $3-\mathrm{m}$ eustatic sea level rise (E), and the 250-year earthquake recurrence are arbitrary values.

simple exposure history and neglecting erosion (see above, section 3.2), the cosmic ray exposure durations deduced from in situ produced ${ }^{10} \mathrm{Be}$ concentrations correspond to the abandonment of the studied shorelines. Samples N05 and N07, collected at 50 and $94 \mathrm{~m}$ amsl (Figure 9b), yield minimum cosmic ray exposure ages of $8.1 \pm 1.8$ and $20.4 \pm 2.4 \mathrm{ka}$, respectively. Between 100 and $280 \mathrm{~m}$ amsl, no prominent morphological feature indicative of paleo-shoreline is observed. This is in good agreement with observations conducted between 150 and $280 \mathrm{~m}$ along the Mancora Tablazo (Figure 4), east of the divide. In this area, no morphological feature that would indicate rupture in the relative sea level fall driving emergence of this flat surface is present.

\subsubsection{Uplift History}

[18] During the past $75 \mathrm{kyr}$ (Figure 11), the eustatic sea level varied significantly and was from 12 to $140 \mathrm{~m}$ lower than today [Imbrie et al., 1984; Chappell and Shackleton, 1986; Bard et al., 1989, 1996; Linsley, 1996; Villemant and Feuillet, 2003]. The Present elevations (50, 90, and $296 \mathrm{~m}$ for samples N05, N07, and N02, respectively) of the dated paleo-shorelines were corrected to take into account these variations and thus to correctly estimate the uplift rates they 


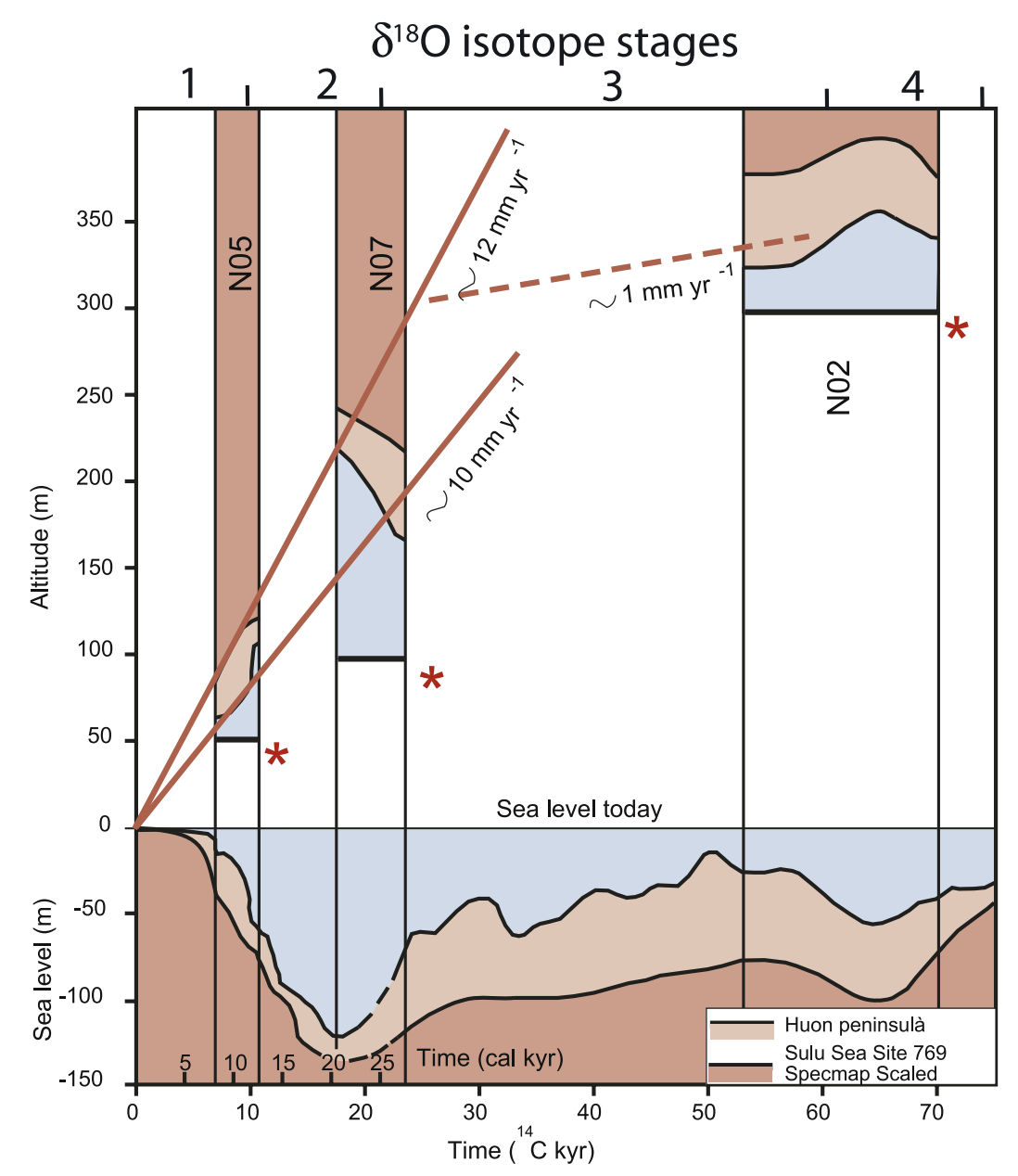

Figure 11. Uplift rate reconstruction (red thick lines and red dashed line) from geomorphic markers (i.e., paleo-shorelines, samples N05, N07, N02) dated using in situ produced ${ }^{10} \mathrm{Be}$ (Table 1). The lower panel shows the past sea level estimates. The pink brown color marks the error envelope in reconstructing the eustatic sea level for the past $75 \mathrm{kyr}$. The upper panel shows the tectonic uplift reconstructed from paleo-shorelines. The thick black lines associated with red stars show to the Present elevation of samples versus the cosmic ray exposure ages (the width of the columns is the 2 sigma error bar). The upper side of each column (above the thick black line with red stars) mirrors the column below present sea level (i.e., the eustatic sea level correction for each sample). The thick red lines show the uplift rate error envelope for samples N05 and N07. Note that they are converging at the origin (i.e., the Present sea level). See text for more details.

experienced since they were formed. The oxygen isotope $\left(\delta^{18} \mathrm{O}\right)$ of the planktonic foraminifers from ODP Site 769 allowed to reconstruct a eustatic sea level curve that matches changes in sea level deduced from coral terraces on the Huon peninsula [Linsley, 1996]. A close correspondence between these two records exists, especially from 20 to $55 \mathrm{ka}$ (i.e., during isotope stages 2 to 3), when the SPECMAP deepocean oxygen isotope record [Imbrie et al., 1984] is $\sim 0.5 \%$ less negative. These SPECMAP values allowed calculating sea level estimates about 40 to $60 \mathrm{~m}$ lower than those from ODP Site 769 and Huon peninsula. If we know the eustatic sea level variation and associated estimates, we can determine the tectonic uplift rate from our data.

[19] We document the following history for emergence of this area. First, at $61.4 \pm 7.2 \mathrm{ka}$, a major earthquake allowed the paleo-bluff at $296 \mathrm{~m}$ amsl to be abandoned. The associated tectonic uplift followed a previous sudden event that left a prominent morphological signature west of El Alto, at $305 \mathrm{~m}$ amsl along the divide. Second, the emergence of the Mancora Tablazo occurred during a stage of low aseismic uplift rate with no record of sudden uplift event. Only east-west trending ridges document discrete reoccupation of this flat area. Because these events occurred during the sea level fall of isotope stages 3 (i.e., from 20 to $50 \mathrm{ka}$ ), they are indicative of very slow or no tectonic uplift acting at that time that is in good agreement with geological evidences. The eustatic sea level fall may account for most of the $130 \mathrm{~m}$ of Mancora Tablazo emergence during isotope stage 3. Third, at $20.4 \pm 2.4$ ka (Figure 9b) began a major sequence of earthquakes that induced a $10-12 \mathrm{~mm} \mathrm{yr}^{-1}$ mean uplift rate (Figure 11) as recorded along profile $\mathrm{P}$ (Figures 4 and 9a).

[20] The Cascajal normal fault (Figure 4) identified from seismic profiles (not shown) trends $\mathrm{N} 20^{\circ} \mathrm{E}$. It bounds the 
Mancora Tablazo block to the west from the Amotapes block to the east. Morphological features including tidal notches and abandoned cliffs document two raised paleoshorelines west of the Amotapes block. The casehardened sandstone cap that characterizes the top of the upper cliff was sampled. This morphological feature located at $342 \mathrm{~m}$ amsl has a minimum cosmic ray exposure age of $18.2 \pm$ $3.8 \mathrm{ka}$ (Table 1). This exposure age yields to an uplift rate of $23.3 \pm 3.4 \mathrm{~mm} \mathrm{yr}^{-1}$ for the seaward side of the Amotapes block during the past 22.1-14.4 kyr when corrected for the eustatic sea level variations and the $3-\mathrm{m}$ gap between the notch and the cap. The uplift rate of the western side of the Amotapes block is 1.5 to 2 times higher than that documented for the western side of the Mancora Tablazo block for the same period of time.

\subsection{The Southern Paita-Illesca Segment}

[21] The Paita-Illesca segment (Figure 2) was investigated in the Paita and Illesca areas (Figures 1 and 2). These two sites located $80 \mathrm{~km}$ apart reveal similar situations with barren, rocky, paleo-wave-cut platforms gently sloping $\left(1^{\circ}\right.$ to $\left.4-5^{\circ}\right)$ seaward. The paleo-cliff-platform junction is at 190 and 145-m elevation for the Illesca and Paita areas, respectively. They both extend seaward to elevation ranging between 60 and $70 \mathrm{~m}$ amsl. No major fault exists between these two areas that would suggest potential difference in their tectonic evolution through time. At both sites, quartz veins intruding black schist of the Paleozoic basement were sampled. Samples N12 and N10 (location, Figure 2 and Table 1), collected along the paleo-shore platforms at $116 \mathrm{~m}$ amsl (Illesca, Figure 7b) and $82 \mathrm{~m}$ amsl (Paita, Figures $7 \mathrm{a}$ and $7 \mathrm{c}$ ), have exposure ages of $164.6 \pm 13.7$ and $141.3 \pm 13.2 \mathrm{ka}$, respectively.

[22] Given age uncertainties, the emergence of the shore platform at N12 sampled site (Figure 12) spans the sea level fall between isotopic substage 7e (highstand at $\sim 200 \mathrm{ka}$ ) and Termination II, low stand at $142 \pm 3 \mathrm{ka}$ [Winograd et al., 1997]. As a consequence, a low rate of tectonic uplift is needed for the shore platform to emerge at that time. Moreover, no morphological feature indicative of rupture in the sea level fall driving the emergence of the platform is observed. Subsequently, a major tectonic uplift step preventing the barren rocky platform to be reoccupied must have occurred during the following sea level rise associated with the warm isotopic substage 5e. To calculate the minimum uplift rate preventing any reoccupation of the platform, we use conservative combination of estimates of sea level changes during isotopic stage 6 and substage 5e, associated with an assumed age of the sea level highstand of isotopic substage 5e at $123.5 \mathrm{ka}$ [Winograd et al., 1997]. When sample N12 site was exposed to cosmic rays, it was between $\sim 60 \mathrm{~m}$ (A, Figure 12) and $\sim 121 \mathrm{~m}$ (B, Figure 12) below the sea level highstand of isotopic substage $5 \mathrm{e}$, as extreme values. If emergence of sample N12 site occurred at $164.5+13.3=177.8 \mathrm{ka}(\mathrm{A}$, Figure 12$)$, the calculated uplift rate for preventing reoccupation of the platform is $\sim 1.1 \mathrm{~mm} \mathrm{yr}^{-1}$ as a minimum. If emergence occurred during Termination II between $\sim 140$ and $150 \mathrm{ka}$ (B, Figure 12), the calculated uplift rate ranges from 4.6 to $7.3 \mathrm{~mm} \mathrm{yr}^{-1}$.

[23] Given age uncertainties, the emergence of the shore platform at N10 sampled site (Paita area) spans (C to D,

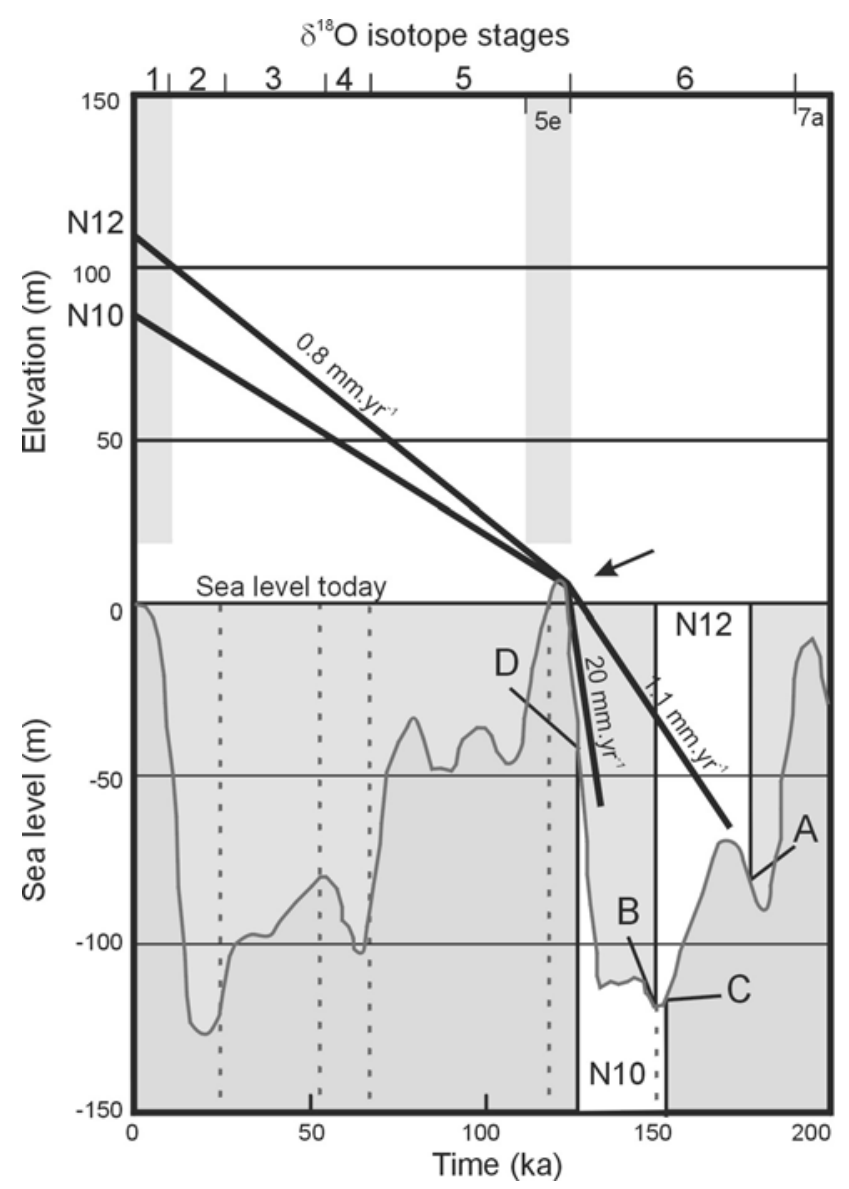

Figure 12. Reconstructed uplift history for samples N10 and N12 collected along the Paita-Illesca segment. The past sea level estimates are from SPECMAP deep-ocean isotope record [Imbrie et al., 1984]. The uplift tectonic phase roughly match the sea level rise during isotope stage 6 to substage 5e. The arrow shows the point where decelerating uplift rate occurred. See text for more details.

Figure 12) the low stand of isotopic stage 6 and the sea level rise of isotopic substage 5e [Winograd et al., 1997; Villemant and Feuillet, 2003]. As at Illesca, a conservative combination of data, including a vertical displacement of $87 \mathrm{~m}$ [82 $\mathrm{m}$ amsl (altitude of sample N10 today) $+5 \mathrm{~m}$ (sea level highstand of isotopic substage $5 \mathrm{e}$ was higher by $5 \mathrm{~m}$, as a minimum, than today)] applied for sample N10, yields to a unique solution with an uplift rate of $13.4 \mathrm{~mm} \mathrm{yr}^{-1}$ occurring during the sea level rise following Termination II. However, the uplift of this area may have begun earlier at $154.5 \mathrm{ka}$ (Table 1) allowing a possible higher vertical displacement of $105 \mathrm{~m}$. This assumption yields to an uplift rate ranging from 3.0 to $9.5 \mathrm{~mm} \mathrm{yr}^{-1}$ between 154.5 and $123.5 \mathrm{ka}$ [Winograd et al., 1997]. Whatever the interpretation is, the vertical tectonic history of N10 and N12 sampled sites (Figure 12) documents that both sites must have uplifted at rates ranging from 1.1 to $20 \mathrm{~mm} \mathrm{yr}^{-1}$ before the highstand at $123.5 \mathrm{ka}$. Subsequently, the Paita-Illesca segment entered a lower uplift rate of less than $0.8 \mathrm{~mm} \mathrm{yr}^{-1}$.

[24] Samples N11 (Paita area) and N13 (Illesca area) were collected (Figure 2) as reference samples for samples N10 and N12, respectively. Samples N11 and N13 are at the 
Present sea level and $10 \mathrm{~m}$ amsl, respectively, in similar morphological situations. Surprisingly, these samples revealed close cosmic ray exposure ages of $5.1 \pm 1.2$ and $6.0 \pm 1.4 \mathrm{ka}$ (Table 1), older than expected. At these sites, no major sea level shift occurred during the past 6.3-3.9 and 7.4-5.6 kyr, respectively. At the site of sample N11, located at the Present shore platform cliff break (Figure 7a), the tectonic uplift compensated the eustatic sea level rise during the past 6.3-3.9 kyr. Because the eustatic sea level rise was no more than $\sim \pm 1 \mathrm{~m}$ during the past $\sim 7 \mathrm{kyr}$ [Milne et al., 2005], the tectonic uplift rate along the Paita-Illesca segment is assumed to be less than $0.15 \mathrm{~mm} \mathrm{yr}^{-1}$ for this period of time.

[25] Two end-member issues arose from the data. The first one assumes that Illesca (sample N12) and Paita (sample N10) sites evolved differently through time, the Illesca site emerging earlier than Paita. This issue minimizes the uplift rate occurring at Illesca site during sea level rise following Termination II. The second one assumes that the Illesca site evolved similar to that documented at Paita. At both sites, most of the uplift occurred during sea level rise from the low stand at Termination II to isotope substage 5e highstand that maximizes the uplift rate. After correction of sea level rise during isotopic substage 5e, the cumulated tectonic uplift ranges from 169 to 207 and is $\sim 237 \mathrm{~m}$ at N10 and N12 sample sites, respectively. During isotopic substage 5e (i.e., between 117 and $130 \mathrm{ka}$ ), sea level rises 120-130 m within probably less than $10 \mathrm{kyr}$ [Linsley, 1996; Winograd et al., 1997; Gallup et al., 2002]. The calculated uplift rate thus ranges from 16.9 to $20.7 \mathrm{~mm} \mathrm{yr}^{-1}$ at N10 sample site and is thus $\sim 10.7 \mathrm{~mm} \mathrm{yr}^{-1}$ at N12 sample site. This second issue suggests the following emergence scenario for the Paita-Illesca segment. (1) During isotope stage 6, an extensive barren rocky wave-cut platform emerged. (2) At 130-135 ka, a major tectonic uplift phase began, efficient enough to prevent any reoccupation during isotope substage 5e sea level rise. The duration of this uplift phase is $\sim 10 \mathrm{kyr}$ with rates ranging from 10.7 to $20.7 \mathrm{~mm} \mathrm{yr}^{-1}$. (3) No evidence exists for major tectonic event occurring during isotope stage 2 to substage $5 \mathrm{~d}$. (4) No appreciable tectonic or eustatic event inducing relative sea level shift occurred during the past 3.9-7.4 kyr.

\section{Offshore Data}

\subsection{General Framework}

[26] The continental margin and shelf along the Golfo de Guayaquil transect (Figure 1), north of the Peru-Ecuador border, exhibits two different areas as regards their tectonic signature and evolution [Witt et al., 2006]. The active N-S trending Domito fault system (DFS, Figure 1), roughly located along the shelf-slope break, bounds these two areas. To the east of the DSF, the northward escape of the North Andean Block controls the Golfo de Guayaquil basin evolution during the past $\sim 2$ Myr. Two major E-W trending fault systems bound the Golfo de Guayaquil to the north; west to east, it includes the Porsoja detachment system (PDS, Figure 1) and the Jambeli detachment system (JDS, Figure 1) that connect each other through the Puna Santa Clara transform system (PSTS, Figure 1). The Porsoja and Jambeli low-angle dipping tectonic features accommodated the northward migration of the North Andean Block. Also, they controlled the location and development of subsidence centers where 3000-4000 m of sediment accumulated since the Lower Pleistocene. To the west of the DFS, the continental margin exhibits active seaward dipping normal faults trending parallel to the trench axis, suggesting that the tectonic regime is mainly controlled by subduction erosion working at depth.

[27] To the south of the Peru-Ecuador border (Figure 2) at $\sim 3^{\circ} 30^{\prime} \mathrm{S}$, the Peru continental margin and shelf show the same distribution and signature of tectonic features and deformation as identified along the Golfo de Guayaquil Ecuadorian transect. The shallow water Banco Peru exhibits highly deformed sediments (seismic profiles not shown), which are located in the southward prolongation of the complex zone identified along the DFS. To the west of Banco Peru, the continental margin exhibits subductionrelated normal faults trending parallel to the trench. To the east of Banco Peru, two major fault systems, the Zorritos and Tumbes detachment systems paralleling the coast, extend from the Tumbes area to north of Cabo Blanco at $4^{\circ} 15^{\prime} \mathrm{S}$. To the south, they bound the ZTB (i.e., south of the Golfo de Guayaquil basin), which extends southward to the Cabo Blanco transect as evidenced by free-air gravity anomalies [Sheperd and Moberly, 1981]. To the south of Cabo Blanco, the continental margin and shelf exhibit deeprooted detachment faults paralleling the $\mathrm{N}-\mathrm{S}$ trending coastal line and trench axis. This subduction-related tectonic deformation and style characterizes the Peru margin between Cabo Blanco and $7^{\circ} 30^{\prime} \mathrm{S}$.

\subsection{The Zorritos-Tumbes Detachment System}

[28] To the north of Cabo Blanco, the Peru shelf extends $70-80 \mathrm{~km}$ in an E-W direction, from the shoreline to Banco Peru. Two nearshore major active fault systems control the subsidence of this area. From north to south, it includes the Tumbes and the Zorrito detachment systems (lines 1 and 2, Figure 13). The Tumbes detachment system exhibits three major flat faults (TD1-3, line 1, Figure 13) dipping seaward (i.e., to the NNW) with strong signature on profile. These flat faults parallel each other at distances varying from 0.3 to $0.6 \mathrm{~s}$ twtt. These faults, deeply rooted down to $5-6 \mathrm{~s}$ twtt, connect to each other as they flatten at depth. The dip of the fault ramps is steepening up section. These faults exhibit the clear signature of a detachment fault system. Each of these three faults is associated with the development of a rollover fold. An accumulation of more than $1.5 \mathrm{~s}$ twtt thick sequence of sediment unconformably overlies the northern fault (TD1, line 1, Figure 13) and the associated rollover fold. Southward, the accumulation of sediment that unconformably overlies the TD2 fault (line 1, Figure 13) is thinner being $0.5 \mathrm{~s}$ twtt in thickness. Only the southern fault (TD3, line 1, Figure 13) is clearly active, showing seafloor displacement. The Tumbes detachment fault system migrated southward (i.e., landward) through time, as did the associated unconformities (U1 to U3, line 1, Figure 13). This migration is associated with a landward shift of depocenters, participating in the ZTB (i.e., southern Golfo de Guayaquil basin) development. Because the Zorritos detachment (Figures 2 and 13) parallels the Tumbes detachment system at depth, we assume that it evolved similar to the Tumbes detachment system and participated in the process of landward migration of the coastline 


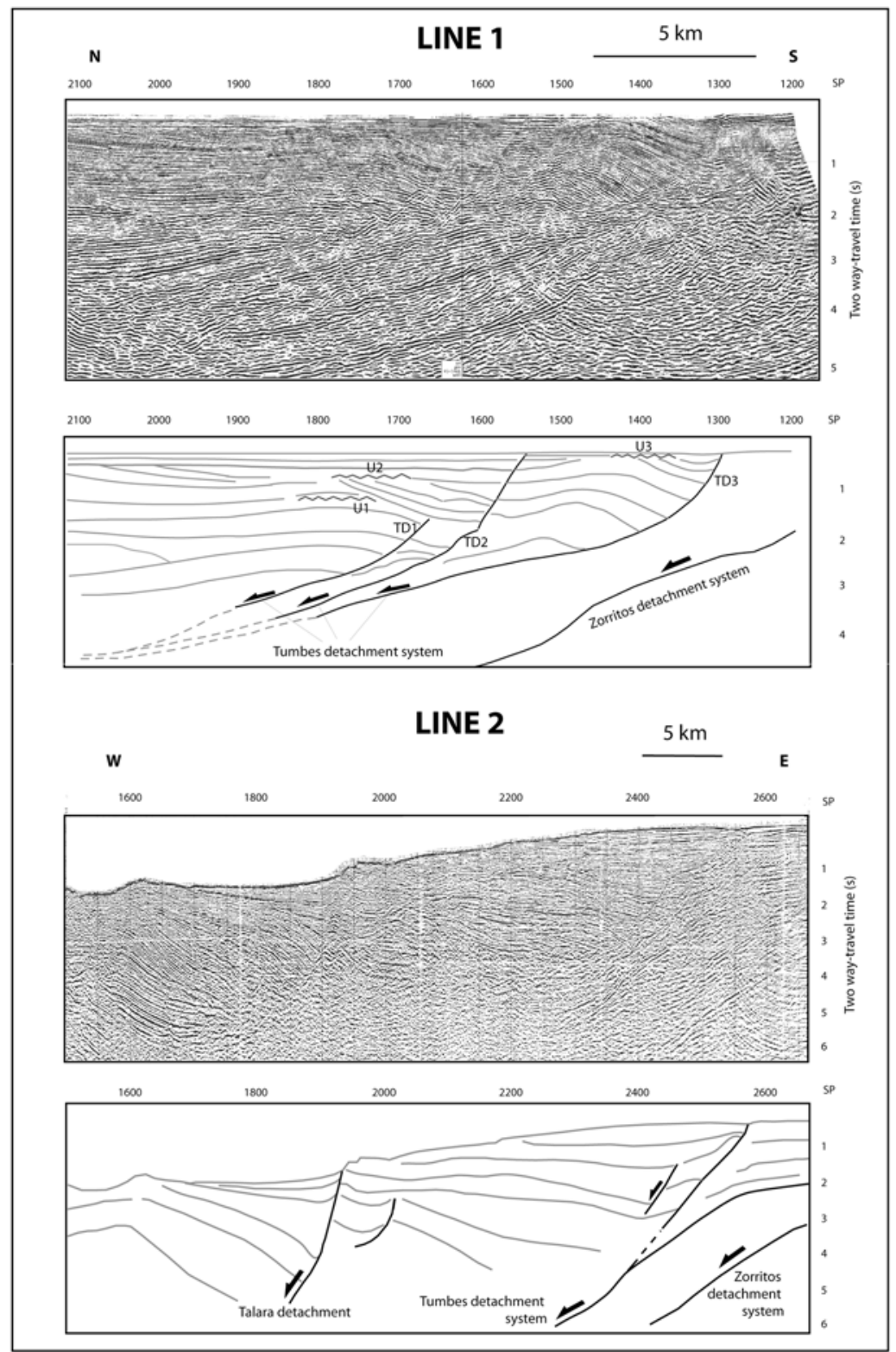

Figure 13. Sections showing the Tumbes and Zorritos detachment systems participating in the southward migration of the southern edge of the Zorritos-Tumbes basin (i.e., the southern Golfo de Guayaquil basin). Unconformities U1 to U3 are identified along profile 1, they recorded the southward marine transgression through time. TD1, TD2, TD3, Tumbes detachments 1 to 3. See text for more details. Line 2 shows the northern Talara fault, which extends southward along profiles 3 and 4 (Figure 16). Location of profiles is shown in Figure 2. Vertical exaggeration at seafloor $=\sim 2$.

through time. Being the fault systems subparallel to the coastline supports the assumption of their control on the coastline evolution.

\subsection{Subduction-Related Normal Faulting}

[29] During the ANDINAUT cruise (23 February to 21 March 1999; Jacques Bourgois, chief scientist) of the R/V L'Atalante, geophysical survey employing EM12 multibeam echo sounding was conducted along the northern Peru margin. A $100 \%$ coverage bathymetric map of the Peru trench was obtained between $3^{\circ} 30^{\prime}$ and $7^{\circ} 30^{\prime} \mathrm{S}$. The map extends to within 1000- to 2000-m water depth on the landward side. Subsequently, we obtained more than
$4000 \mathrm{~km}$ of industrial seismic records acquired by PERUPETRO in this area. These data cover the shelf and the continental slope down to 3-4000 $\mathrm{m}$ water depth offering considerably new information on the area between the coastline and the ANDINAUT cruise records in deeper water depth. When possible, interpretations of the seismic data were related to swath mapping, allowing projecting of previous identified structures. In that manner, the main scarp associated with the Sechura detachment [Bourgois et al., 1988, 1993; von Huene et al., 1989] located at the middle-upper slope boundary along the CDP3 transect is identified to extend $150 \mathrm{~km}$ to the south (Figure 2; line 6, Figure 14), being a major regional fault. The Sechura 


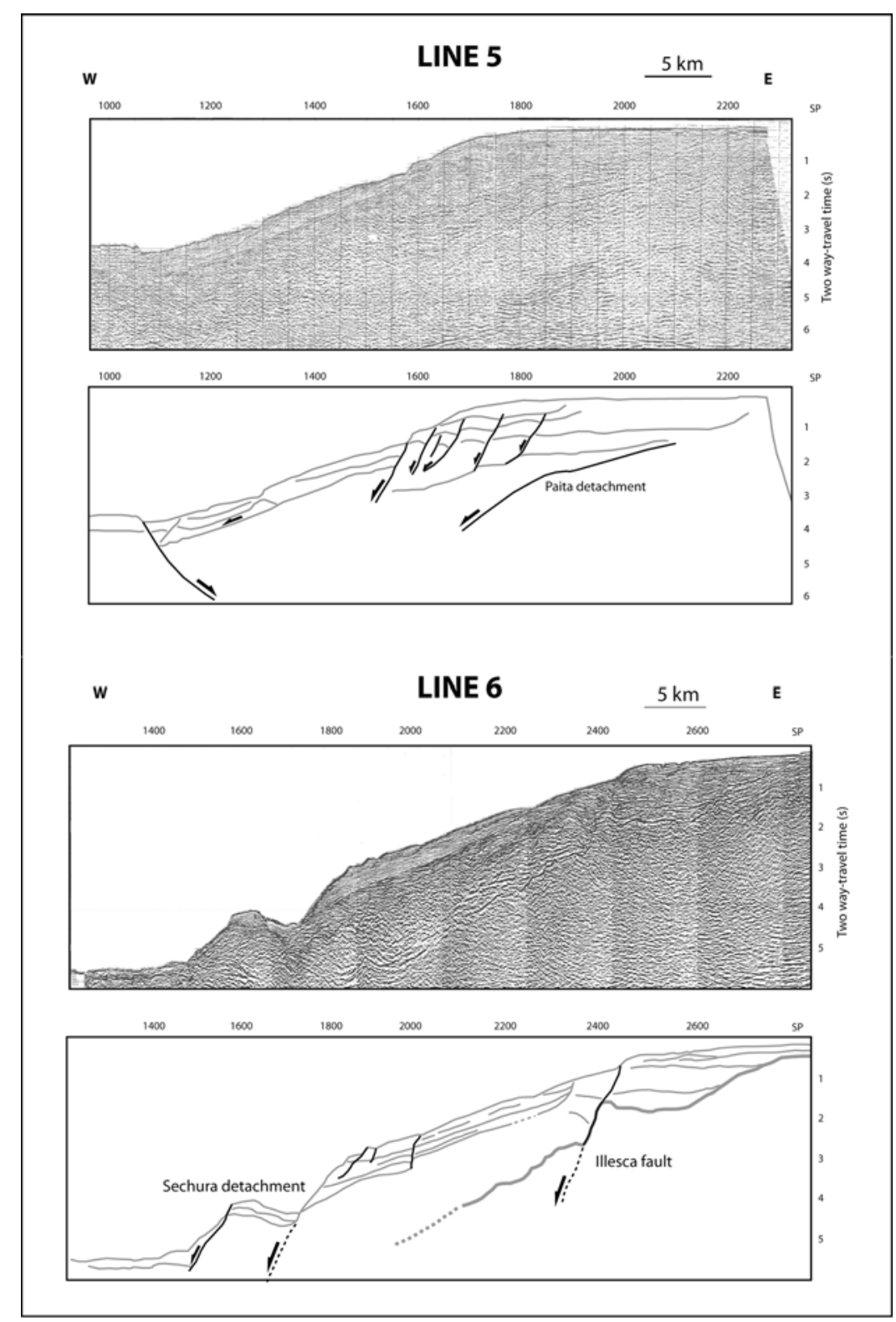

Figure 14. Line 5 along the Paita segment (Figure 2) shows normal faulting at the upper slope-shelf break. We suspect that a major detachment exists at depth (i.e., the Paita detachment). Line 6 shows the Sechura fault previously described as a major detachment along the CDP3 profile [Bourgois et al., 1988, 1993; von Huene et al., 1989]. Note the development of the Illesca normal fault upslope. See text for more details. Location of profiles is shown in Figure 2. Vertical exaggeration at seafloor $=\sim 2$.

detachment along which $800-1000 \mathrm{~m}$ downslope motion occurred during the past $400 \mathrm{kyr}$ [Bourgois et al., 1993] extends to the north. As it bends seaward, it connects to the trench-slope break, suggesting that this major fault, identified down to $5 \mathrm{~km}$ below seafloor along the CDP3 transect, presumably connects the subduction channel at depth.

[30] North of $5^{\circ} \mathrm{S}$, line 3 (Figure 15) exhibits sediment pounding a flat middle slope basin bounded to the east by a major fault dipping seaward. The sediment infill onlaps the basement basin floor to the west. It shows a fan shape signature with clear landward dipping reflections and a total thickness increasing considerably landward. Along the fault, the sediment accumulation, including the most recent sequences, recorded tectonic deformation. We assume that the fault bounding the flat floor basin is a major active detachment (i.e., the Talara detachment). The prolongation of this major fault was identified in the seismic records as shown along lines 2 (Figure 13) and 4 (Figure 15), to the north and to the south, respectively. It allows us to trace this fault in the bathymetry (Figure 2). This major active tectonic feature extends about $80 \mathrm{~km}$ from $4^{\circ}$ to $4^{\circ} 45^{\prime} \mathrm{S}$. The Talara detachment exhibits a strong signature in the seafloor morphology including major scarps and canyons both trending parallel to the coastline. At $4^{\circ} 45^{\prime} \mathrm{S}$, the trending direction of the Talara fault changes abruptly from $\mathrm{N} 20^{\circ} \mathrm{E}$ to $\mathrm{N} 90^{\circ} \mathrm{E}$ following a 1000 -m-deep canyon that connects the Talara detachment to the trench axis. The Talara detachment and the subduction channel may connect 


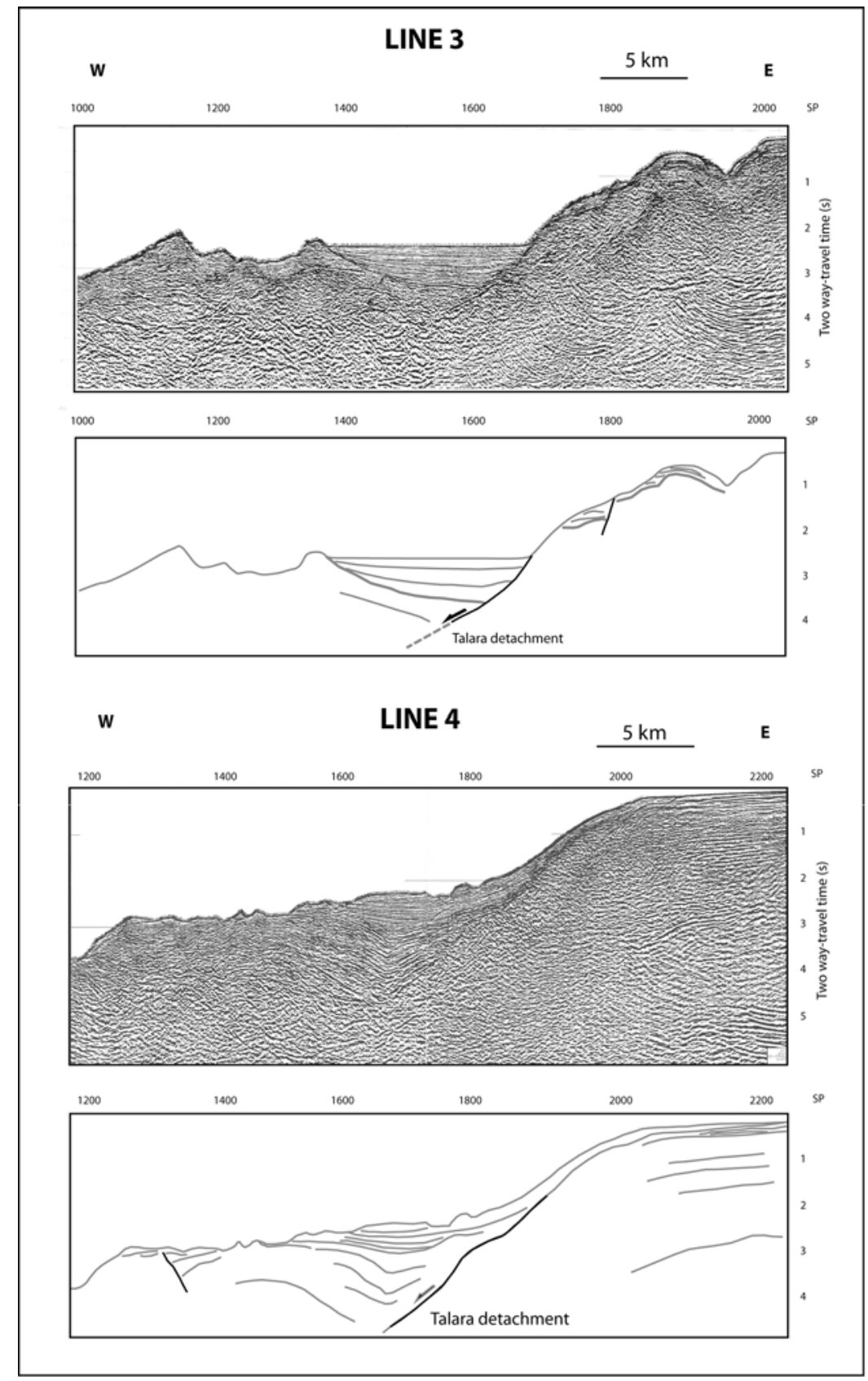

Figure 15. Lines showing the development of the Talara detachment. Note that the detachment is flat (i.e., dipping $\sim 20^{\circ}$ ) at depth. See text for more details. Location of profiles is shown in Figure 2. Vertical exaggeration at seafloor $=\sim 2$.

with each other at depth as we suspect along the Sechura detachment. The calculated amount of downward displacement along the Talara detachment is about $800-1000 \mathrm{~m}$, the horizontal lengthening being $3000-4000 \mathrm{~m}$.

[31] The Sechura and Talara detachments evidence an 80to $120-\mathrm{km}$ first-order segmentation extending across the lower and middle slopes between the trench axis and water depth ranging from 1000 to $3000 \mathrm{~m}$. This segmentation includes a specific segment located between the Sechura and Talara segments: the Paita segment (Figure 2), which extends from $4^{\circ} 40$ to $5^{\circ} 20^{\prime} \mathrm{S}$. Line 5 (Figure 14) that crosscuts the Paita segment exhibits normal faults. From seismic records, we suspect that a major detachment (i.e., the Paita detachment) exists at depth, this area being under a similar tectonic regime than that evidenced along other segments.

\section{Discussion and Conclusion}

\subsection{Strain Buildup and Segmentation}

[32] Abundant pieces of evidence show that the coastal area of northern Peru behaves as a long-term uplift accumulation zone. Our study following that of DeVries [1988] reveals that the shoreline of the coastal plain located south of Cabo Blanco migrated 35 to $100 \mathrm{~km}$ seaward (Figure 16) during the past 200 kyr. Conversely, the Zorritos-Tumbes 


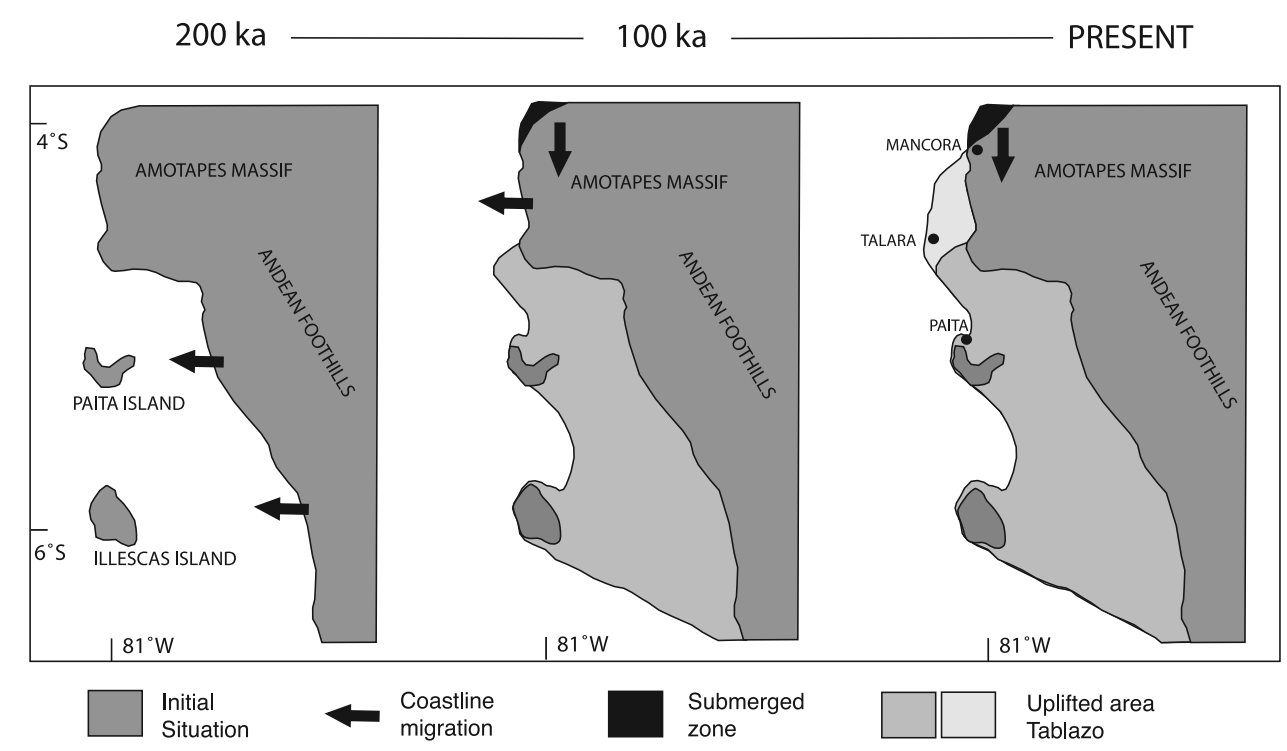

Figure 16. Evolution of the extent of inland seas since $200 \mathrm{ka}$, modified from the study of DeVries [1988]. The shoreline migrated to the west through two main tectonic phases, the first one occurred between $\sim 125$ and $\sim 150-180 \mathrm{ka}$ along the Paita-Illesca segment, and during the past 20-23 kyr along the Cabo Blanco segment. Note that the coastline migrated landward along the southern edge of the Tumbes-Zorritos basin (i.e., the southern edge of the Golfo de Guayaquil basin), north of Mancora during about the same period of time.

basin (i.e., the southern edge of the Golfo de Guayaquil basin) coastline migrated landward during the same period of time, indicating considerable control of the Peru coastal plain tectonics by the Golfo de Guayaquil basin dynamics, north of Mancora. Therefore, we infer that the long-term shelf uplift of the Peru margin south of Cabo Blanco is related to the subduction zone behavior, as is the coeval continental slope subsidence.

[33] During the past $\sim 70 \mathrm{kyr}$, the net uplift recorded along the Cabo Blanco segment is $300-350 \mathrm{~m}$. For the past $128.1-178.2 \mathrm{kyr}$, net uplift at the Paita and Illesca sites is 237 and $169 \mathrm{~m}$, respectively. The reconstructed uplift history of the studied area not only documents the buildup of the coastal relief but also suggests time correlation between the major tectonic uplift steps and eustatic deglacial sea level rises over the past $200 \mathrm{kyr}$ (Figure 17). Conversely, the last two glacial sea level falls seem to be characterized by low rates of tectonic uplift. Along the Cabo Blanco segment (Figures 11), the most recent tectonic step is coeval with the sea level rise that follows the Last Glacial Maximum (LGM). During the sea level fall of isotope stages 2 and 3, a low tectonic uplift rate of less than $\sim 0.8 \mathrm{~mm} \mathrm{yr}^{-1}$ may account for the shoreline retreat. At Paita and Illesca sites, we document that a major tectonic uplift occurred during sea level rise after Termination II. Because it yields to uplift rates ranging from 10.7 to $20.7 \mathrm{~mm} \mathrm{yr}^{-1}$, similar to those estimated along the Cabo Blanco segment, we favor the assumption that uplift occurred during the deglacial sea level rise after Termination II at both sites. During a part of the most recent tectonic step that affects the Cabo Blanco segment, the Paita-Illesca segment shows a different tectonic history with low rate of vertical displacement. Our data suggest that the northern Peru coastal plain is segmented into two tectonic subregions: the Cabo Blanco segment and the Paita-Illesca segment.
[34] Permanent strain buildup along the offshore continental margin is concentrated along the middle and the lower slope. In these areas, the long-term subsidence is controlled by major detachments, which probably connect the subduction channel at depth. The permanent deformation of the continental slope includes lengthening of the margin basement, rollover fold development [Bourgois et al., 1993], and related catastrophic debris avalanche. The unloading induced by these deformations would diminish pore fluid pressure arising from lithostatic overburden and accelerate the upward migration of fluid [Dia et al., 1993]. It was suggested [Murauchi and Ludwig, 1980] that the mechanism of upward migration of fluid released during subduction is capable of weakening the base of the upper plate. Such weakening might contribute to the subduction erosion of this base. The strain buildup of the middle and lower slope areas is the signature of the subduction erosion process working at depth at least along the lower and the middle slopes. The major tectonic features such as the active Talara and Sechura detachments document a tectonic segmentation of the continental margin along the middle and lower slopes. No evidence exists to correlate in space the tectonic segmentation of the coastal plain to that of the continental slope. The age of the detachment scarp, which results from cumulative effects of successive events, and the average slip interval recurrence are unknown. However, the age at which the Sechura detachment began to work was estimated to be $\sim 400 \mathrm{ka}$ [Bourgois et al., 1993].

[35] No clear tectonic correlation in time exists between the coastal plain and the continental margin segmentations or in space either. Subducting plate anomalies, such as crust thickness and seafloor relief, are identified to produce structural differences on the adjacent middle to upper continental slope. Along Costa Rica [von Huene et al., 2000], these structural differences were proposed to have 


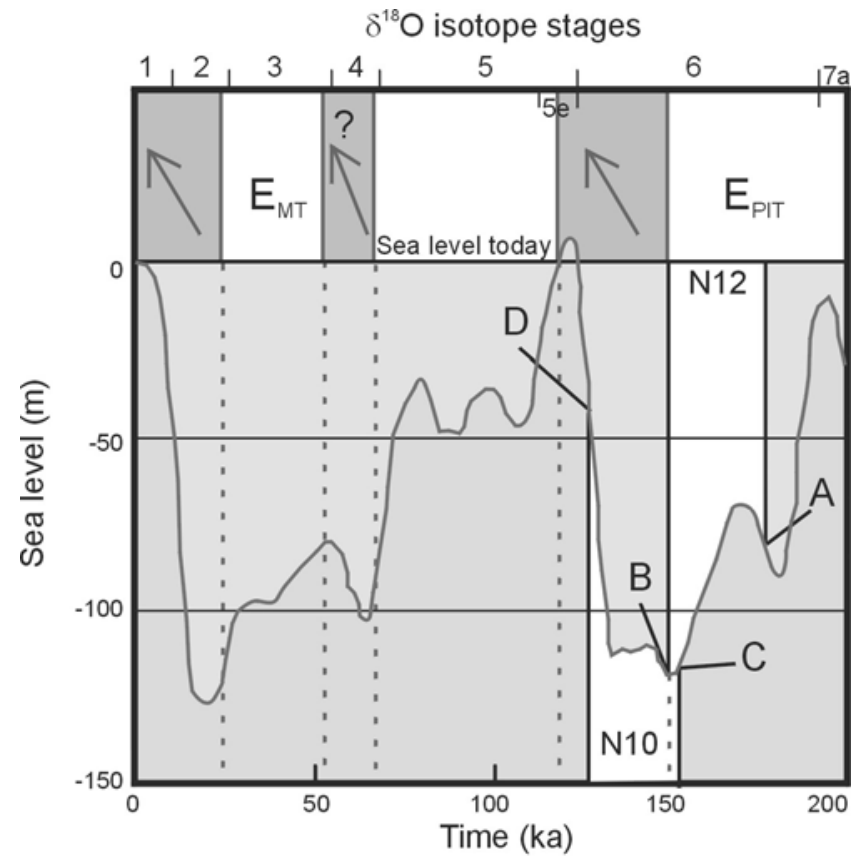

Figure 17. Diagram showing the correlation between the tectonic uplift phases (arrow in the upper panels) and the eustatic deglacial sea level rises. $2 \sigma$ error bar of N10 and N12 samples is shown (light gray). (a-d) The extreme age values for N12 and N10 sample sites to emerge. The past sea level estimates are from SPECMAP deep-ocean isotope record [Imbrie et al., 1984]. The uplift tectonic phases roughly match the sea level rises during isotope stages 2 and 6 to 1 and substage 5e, respectively. The emergence of the Mancora tablazo $\left(E_{\mathrm{MT}}\right)$ and the Paita-Illesca Tablazos $\left(E_{\mathrm{PIT}}\right)$ probably occurred during the sea level falls of isotope stages 3 and 6, respectively. No geomorphic evidence of sudden tectonic event exists during these eustatic falls. See text for more details. apparent effect extending $120 \mathrm{~km}$ landward, to within the volcanic arc. Control of the convergent margin tectonics by topographic anomalies of the subducting Nazca plate, if it exists off northern Peru, shows no clear signal landward the middle slope.

\subsection{Earthquake Recurrence, Uplift Rate, Seismogenic Behavior}

[36] The most recent uplift step at Cabo Blanco is associated with a sequence of 16 major earthquakes (Figure 9a). Because the uplift phase spans the past 20-23 kyr, an earthquake recurrence interval of $1250-1437 \mathrm{yr}$ is calculated. Since most of the largest earthquakes are interplate underthrusting events, we assume that the seismogenic behavior (Figure 18) of the subduction zone at depth and its evolution through time control the vertical movements at the northern Peru forearc. However, the net uplift along the Cabo Blanco and Paita-Illesca segments is roughly similar but shifted in time being $\sim 0-23$ and $\sim 125-180 \mathrm{ka}$, respectively. Because the Paita-Illesca segment recorded a low uplift rate during the past $\sim 125 \mathrm{kyr}$, we assume that the time needed to rebuild the strain for a sequence of major earthquakes to be triggered spans more than a complete glacial-deglacial cycle (i.e., more than 120-150 kyr).

[37] In order to make a comparison with other coastal regions where preservation of coastal landforms results from tectonic uplift, a linear distribution of uplift through time was assumed for the past 160-200 kyr. This led to uplift rates ranging from 1.5 to 1.8 and 0.5 to $1.2 \mathrm{~mm} \mathrm{yr}^{-1}$ for the Cabo Blanco and Paita-Illesca segments, respectively, which are similar to those estimated elsewhere along active margins. The 6 to 10 times higher uplift rates at northern Peru are calculated from tectonic step duration that also allows demonstrating the discrete behavior of processes at work.

[38] One key aspect of subduction zone is the fact that just a small segment of the plate interface is seismogenic, the maximum depth of the seismically coupled zone, the downdip limit, being a transition from unstable to stable sliding along the plate interface [Tichelaar and Ruff, 1993]. For some subduction zones, the shallowest few kilometers of the plate interface is nonseismogenic. The upper cutoff of

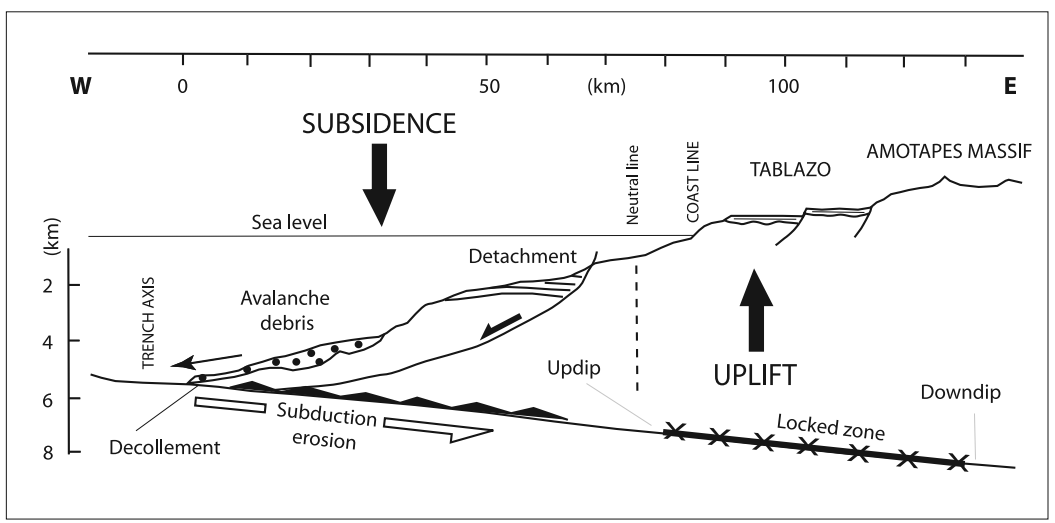

Figure 18. Distribution of permanent deformation along the northern Peru forearc area as exemplified along the Cabo Blanco transect. Induced long-term subsidence by subduction erosion working at depth characterizes the continental margin. The long-term uplift (i.e., long-term relief created) of the coastal plain (tablazo) suggests that the seismogenic zone is periodically locked at depth. See text for more details. 


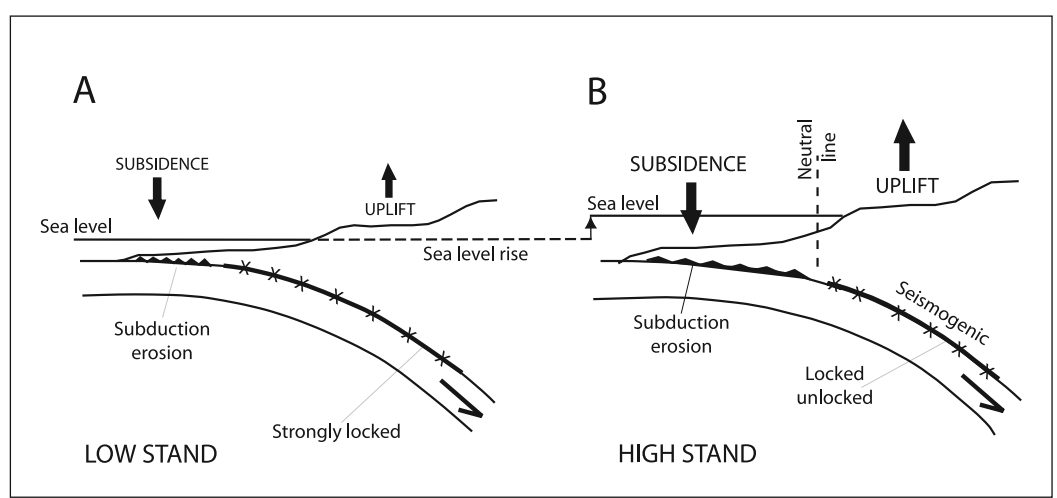

Figure 19. Eustacy feedback coupling to seismogenic behavior of the northern Peru subduction zone. (a) During sea level fall, pore fluid pressure diminishes along the subduction channel inducing a possible seaward migration of the locked zone that would reach a maximum by the end of the eustatic low stand. (b) During eustatic sea level rise, pore fluid pressure increases along the subduction channel. This in turn is capable to weaken the previously locked zone along the plate interface. Such weakening might contribute to the locked zone to enter a long-lived sequence of major earthquakes. See text for more details.

seismicity is the updip limit of the seismogenic zone. Along the northern Peru segment (Figure 18), we infer that the nonseismogenic zone extends along the continental slope where high decoupling at plate interface exists as evidenced by deep-rooted detachment faulting and long-term subsidence. The locked-unlocked transition zone of the seismogenic zone is located inward, the neutral line being located in the few kilometers of the upper slope-shelf area.

[39] The earthquake cycle concept [Savage, 1983; Thatcher, 1984, 1986; Clague, 1997] consists of an interseismic period of strain buildup associated with a locked zone and abrupt coseismic stress release during an earthquake. Between earthquakes when the plate boundary is locked, the seaward edge of the continent is dragged down, and a flexural bulge forms farther inland. During an earthquake, when elastic strain release occurs, the area seaward of the locked zone is uplifted, and the flexural bulge collapses. The correlation between the location of the downdip edge of the seismogenic zone at plate interface with the location of the coastal line [Ruff and Tichelaar, 1996] and the correlation between the downdip edge with the location of the interseismic uplift-bulge hinge [Clague, 1997] are evidences suggesting that the coastal area is the key zone to record the permanent deformation left by the earthquake cycle. In the case of the northern Peru subduction zone, the subsidence of the continental margin and the uplift of the coastal area appear to be coseismic [Bourgois et al., 1993] and in inverse location along profile as predicted by the earthquake cycle concept [Savage, 1983; Thatcher, 1984]. Also, no bending of the uplifted coastal plain is observed. Coseismic uplift of major blocks with no appreciable tilting is the recorded tectonic style, the permanent deformation acting through major faults and/or detachments. Also, no notable minor faulting is observed onshore. This situation suggests that the seismogenic zone is periodically strongly locked with low accumulation of interseismic elastic strain to be recovered during coseismic rupture. At northern Peru, the coastal area uplifted vertically through the earthquake cycle as tectonic block.

[40] Wang and Hu [2006] expanded the classical Coulomb wedge theory for accretionary prisms by considering temporal variations of stresses along the subduction megathrust and within the outer wedge. In the great earthquake cycles, the seismogenic zone (i.e., below the inner wedge at depth) alternates between interseismic locking and coseismic slip, the outer wedge switches between stable and critical states. Applying their model to margins dominated by subduction erosion, they show that frontal prism of those margins is expected to be similar to outer accretionary wedges (i.e., margins under subduction accretion) in switching between stable and critical states in the earthquake cycles. Along margins with basal erosion such as northern Chile and Peru, the coseismic strength of the subduction megathrust is the strength of the frontal prism material, the decollement being not distinctly defined during earthquake. The pore fluid pressure ratio and the state of basal friction property (i.e., basal erosion) along the frontal prism are expected to be lower during the period between large earthquakes when the seismogenic zone is either locked, as is currently the situation off Peru [Gagnon et al., 2005]. As observed along the coastal plain of northern Peru, Wang and $H u$ [2006] demonstrated that the inner wedge generally stays in the stable regime throughout earthquake cycles acting as an apparent backstop and providing a stable environment.

\subsection{Eustacy and Seismogenic Behavior Feedback Coupling}

[41] Since the most recent uplift phase along the Cabo Blanco segment and the associated sequence of major earthquakes are coeval with the last deglacial sea level rise, we infer that eustacy may exert important feedback coupling to seismogenic behavior of the Peru subduction zone. We suspect that the size and location of the seismogenic zone and the seismic coupling at plate interface are controlled by eustacy. We suggest that the $40-\mathrm{km}$ westward migration of the coast during the most recent tectonic phase identified along the Cabo Blanco segment reflects the shift of the updip limit at depth. The eustacy must induce pore fluid pressure variations along the plate interface that in turn may control the location and/or extension of the seismogenic zone through time. During sea level fall (Figure 19a), 
pore fluid pressure diminishes along the subduction channel inducing a possible seaward migration of the locked zone that would reach a maximum by the end of the eustatic low stand. Conversely, during eustatic sea level rise (Figure 19b), the pore fluid pressure increases along the subduction channel. This in turn is capable to weaken the previously locked zone along the plate interface. Such weakening might contribute to the locked zone to enter a long sequence of major earthquakes.

[42] Laboratory experiments have shown that the effective coefficient of friction on the plate interface is sensitive to many factors, including differences in material properties, presence or absence of fluids, seafloor roughness, slab geometry, temperature, and contact time. Therefore, a migration of the seismogenic zone can modulate the seismogenic behavior at the plate interface. Laboratory studies on the frictional behavior of sliding rock surfaces also show that changes in shear tractions induce changes in seismogenic behavior [Marone, 1998; Song and Simons, 2003]. At the western Tokai area (central Japan), it has been demonstrated [Ozawa, 2002] that the current aseismic slip is currently changing stress state, which may induce catastrophic event with a Coulomb Failure Stress ( $\triangle$ CFS) change of $\sim 5 \mathrm{kPa}$. At Izu Island, it was inferred that a $\triangle \mathrm{CFS}$ as small as $\sim 0.5 \mathrm{kPa}$ may have triggered an aseismic slip event in the western Tokai [Ozawa, 2002]. These small values of the $\triangle \mathrm{CFS}$ illustrate that factors controlling the seismic behavior of seismogenic zones are very sensitive at the earthquake cycle timescale. Because $\triangle \mathrm{CFS}$ is defined as $\Delta \mathrm{CFS}=\Delta \tau+\mu\left(\Delta \sigma_{\mathrm{n}}+\Delta P_{\mathrm{f}}\right)$, where $\Delta \tau$ and $\Delta \sigma_{\mathrm{n}}$ are the shear and normal stress changes, respectively, and $\Delta P_{\mathrm{f}}$ is the change in pore fluid pressure, we assume that a small change in pore pressure of the system such as eustaticinduced variations may trigger large-scale change in the hydraulic properties along the seismogenic zone. Our results also provide support for a relationship between eustatic sea level variations and seismic behavior of the northern Peru subduction zone, at the timescale of the succession of late Pleistocene ice age. Since evidence of close relationship between the time-varying amplitudes of orbital forcing and the time-varying amplitudes of late Pleistocene ice age (i.e., eustatic sea level variations) exists [Imbrie et al., 1984], Earth's orbital variations are also a potential external cause that may control the physical processes at work along the northern Peru seismogenic zone.

[43] Acknowledgments. Reviews by Peter A. Cawood, Dave Scholl, and an anonymous reviewer greatly improved the quality of this manuscript. We thank Greg Balco, Jacques Boulègue, and Remy Louat for interesting discussions and for reviewing drafts of this manuscript. The Centre National de la Recherche Scientifique (CNRS), the Institut des Sciences de l'Univers (INSU) through the "Reliefs de la Terre" program, and the Institut de Recherche pour le Développement (IRD) provided funding for this research. This work used seismic and drill data provided by PERUPETRO (Lima, Peru). We are particularly grateful to Rolando Bolaños, Belizario Cornejo, and Oscar Gil who contributed most directly to our success. The EM12 bathymetric data were acquired during the ANDINAUT cruise (Jacques Bourgois, chief scientist) of the R/V L'Atalante (GENAVIR/IFREMER). We thank the captain and the crew of the R/V L'Atalante for their efficient work. Thanks are also due to all the ANDINAUT cruise members for their enthusiastic cooperation.

\section{References}

Alpers, C. N., and G. H. Brimhall (1988), Middle Miocene climatic change in the Atacama Desert, northern Chile; evidence from supergene mineralization at La Escondida, Geol. Soc. Am. Bull., 100(10), 1640-1656.
Aubouin, J., R. von Huene, M. Baltuck, R. Arnott, and J. Bourgois (1982), Leg84 of the Deep Sea Drilling Project, subduction without accretion: Middle America trench off Guatemala, Nature, 247, 458-460.

Aubouin, J., J. Bourgois, and J. Azema (1984), A new type of active margin: The convergent-extensional margin, as exemplified by the Middle America trench off Guatemala, Earth Planet. Sci. Lett., 87, $111-126$.

Bard, E., R. Fairbanks, M. Arnold, P. Maurice, J. Duprat, J. Moyes, and J. C. Duplessy (1989), Sea-level estimates during the last deglaciation based on $\delta^{18} \mathrm{O}$ and accelerator mass spectrometry ${ }^{14} \mathrm{C}$ ages measured in Globigerina bulloides, Quat. Res., 31, 381-391.

Bard, E., B. Hamelin, M. Arnold, L. F. Montaggioni, G. Cabioch, G. Faure, and F. Rougerie (1996), Deglacial sea-level record from Tahiti corals and the timing of global meltwater discharge, Nature, 382, 241-244.

Berryman, K. R. (1987), Tectonic processes and their impact on the recording of relative sea-level changes, in Sea-surface studies-A global view, edited by R. E. Wallace and R. J. N. Devoy, pp. 127-161, Croom Helm, London.

Bosworth, T. O. (Ed.) (1922), Geology of the Tertiary and Quaternary Periods in the Northwest part of Peru, 434 pp., MacMillan, New York.

Bourgois, J., et al. (1988), SeaBeam and seismic reflexion imaging of the tectonic regime of the Andean continental margin off Peru $\left(4^{\circ} \mathrm{S}\right.$ to $\left.10^{\circ} \mathrm{S}\right)$, Earth Planet. Sci. Lett., 87, 111-126.

Bourgois, J., Y. Lagabrielle, P. De Wever, E. Suess, and NAUTIPERC team (1993), Tectonic history of the northern Peru convergent margin during the past $400 \mathrm{ka}$, Geology, 21, 531-534.

Bourles, D. L. (1988), Etude de la géochimie de l'isotope cosmogénique ${ }^{10} \mathrm{Be}$ et de son isotope stable en milieu océanique. Application à la datation de sediments marins, PhD, Paris Sud Centre d'Orsay University, Orsay, France.

Braucher, R., E. T. Brown, D. L. Bourlès, and F. Colin (2003), In situproduced ${ }^{10} \mathrm{Be}$ measurements at great depth: Implications for production rates by fast muons, Earth Planet. Sci. Lett., 211, 251-258.

Brown, E. T., E. J. Brook, G. M. Raisbeck, F. Yiou, and M. D. Kurz (1992), Effective attenuation lengths of cosmic producing ${ }^{10} \mathrm{Be}$ and ${ }^{26} \mathrm{Al}$ in quartz, implications for exposure age dating, Geophys. Res. Lett., 19, $369-372$.

Brown, R., K. Gallagher, A. J. W. Gleadow, and M. A. Summerfield (2000), Morphotectonic evolution of the South Atlantic margins of Africa and South America, in Geomorphology and Global Tectonics, edited by M. A. Summerfield, pp. 255-281, John Wiley \& Sons, Chichester.

Caldas, J., V. Palacios, and V. Puech-Churchill Vela (1980), Geologia de Los Quadrangulos de Bayovar, Sechura, La Redonda, Pta La Negra, Lobos de Tierra, Las Salinas y Morrope, Inst. Geol. Min. Metall. Boll., $32,32-50$.

Chappell, J., and N. J. Shackleton (1986), Oxygen isotopes and sea level, Nature, 324, 137-140.

Chappell, J., Y. Ota, and K. Berrymann (1996), Late Quaternary coseismic uplift history of Huon peninsula, Papua New Guinea, Quat. Sci. Rev., 15, $7-22$.

Clague, J. J. (1997), Evidence of large earthquakes at the Cascadia subduction zone, Rev. Geophys., 35, 439-460.

Clift, P. D., I. Pecher, L. Hutt, N. Kukowski, and A. Hampel (2003), Tectonic erosion of the Peruvian forearc, Lima Basin, by subduction and Nazca Ridge collision, Tectonics, 22(3), 1023, doi:10.1029/ 2002 TC001386.

Cockburn, H. A. P., R. W. Brown, M. A. Summerfield, and M. A. Seidl (2000), Quantifying passive margin denudation and landscape development using a combined fission-track thermochronology and cosmogenic isotope analysis approach, Earth Planet. Sci. Lett., 179, 429-435.

DeVries, T. J. (1984), Neotectonica del area de Cabo Blanco, nordeste del Peru, Bol. Soc. Geol. Peru Boll., 73, 1-14.

DeVries, T. J. (1988), The geology of late Cenozoic marine terraces (tablazos) in northwestern Peru, J. South Am. Earth Sci., 1, 121-136.

DeVries, T. J., et al. (1997), Determining the early history of El Niño, Science, 276, 965-967.

Dia, A., L. Aquilina, J. Boulègue, J. Bourgois, E. Suess, and M. Torres (1993), Origin of fluids and related barite deposits at vent sites along the Peru convergent margin, Geology, 21, 1099-1102.

Dunai, T. J., A. Gabriel, G. Lopez, and J. Juez-Larré (2005), OligoceneMiocene age of aridity in the Atacama Desert revealed by exposure dating of erosion-sensitive landforms, Geology, 33, 321-324.

Gagnon, K., C. D. Chadwell, and E. Norabuena (2005), Measuring the onset of locking in the Peru-Chile trench with GPS and acoustic measurements, Nature, 434, 205-208.

Gallup, C. D., H. Cheng, F. W. Taylor, and R. L. Edwards (2002), Direct determination of the timing of sea level change during Termination II, Science, 295, 310-313.

Hampel, A., N. Kukowski, J. Bialas, C. Huebscher, and R. Heinbockel (2004), Ridge subduction at an erosive margin: The collision zone of 
the Nazca ridge in southern Peru, J. Geophys. Res., 109, B02101, doi:10.1029/2003JB002593.

Hoke, G. D., B. L. Isacks, T. E. Jordan, and J. S. Yu (2004), Groundwatersapping origin for the giant quebradas of northern Chile, Geology, 32(7), 605-608.

Hussong, D. M., and L. K. Wipperman (1981), Vertical movement and tectonic erosion of the continental wall of the Peru-Chile Trench near $11^{\circ} 30^{\prime} \mathrm{S}$ latitude, in Nazca plate: Crustal formation and Andean convergence, Mem. Geol. Soc. Am., vol. 154, edited by L. D. Kulm, J. Dymond, E. J. Dasch, D. M. Hussong, and R. Roderick, pp. 509-524.

Imbrie, J., J. D. Hays, D. G. Martison, A. McIntyre, A. C. Mix, J. J. Morley, N. G. Pisias, W. L. Prell, N. J. Shackleton (1984), The orbital theory of Pleistocene climate: Support from a revised chronology of the marine $\delta^{18} \mathrm{O}$ record, in Milankovitch and Climate: Part 1. NATO ASI Series, edited by A. L. Berger, pp. 269-305, Springer, New York.

Kelsey, H. M., and J. G. Bockheim (1994), Coastal landscape evolution as a function of eustasy and surface uplift rate, southern Cascadia margin, USA, Geol. Soc. Am. Bull., 106, 840-854.

Kulm, L. D., , J. Dymond, E. J. Dasch, D. M. Hussong, and R. Roderick (Eds.) (1981), Nazca Plate: Crustal formation and Andean Convergence, 824 pp., Mem. Geol. Soc. Am., 154.

Kulm, L. D., T. M. Thornburg, E. Suess, J. Resig, and P. Fryer (1988), Clastic, diagenetic and metamorphic lithology of a subsiding continental block: Central Peru forearc, In Proc. ODP Init. Rep. 112, pp. 91-107, edited by E. Suess and R. E. von Huene, Ocean Drilling Program, College Station, TX.

Lagabrielle, Y., B. Pelletier, G. Cabioch, M. Regnier, and S. Calmant (2003), Coseismic and long-term vertical displacement due to back arc shortening, central Vanuatu: Offshore and onshore data following the Mw 7.5, 26 November 1999 Abrym earthquake, J. Geophys. Res., 108(B11), 2519, doi:10.1029/2002JB002083.

Lajoie, K. R. (1986), Coastal Tectonics, in Active tectonics. Studies in Geophysics, pp. 95-124, National Research Council, National Academy Press, Washington, D. C.

Lal, D. (1991a), The present scope of the field of terrestrial cosmogenic nuclides, Science, 6, 744-751.

Lal, D. (1991b), Cosmic ray labeling of erosion surfaces: In situ nuclide production rates and erosion models, Earth Planet. Sci. Lett., 104, 424-439.

Lay, T., H. Kanamori, and L. Ruff (1982), The asperity model and the nature of large subduction zone earthquakes, Earthquake Predict. Res. $1,3-71$.

Linsley, B. K. (1996), Oxygen-isotope record of sea level and climate variations in the Sulu Sea over the past 150,000 years, Nature, 380, $234-237$.

Macharé, J., and L. Ortlieb (1994), Morfoestratigrafia de los tablazos del noroeste Peruano: Neotectonica y fluctuaciones del nivel del mar, paper presented at VIII Congreso Peruano de Geologia, Lima, Peru, 238-241.

Marone, C. (1998), Laboratory-derived friction laws and their application to seismic faulting, Annu. Rev. Earth Planet. Sci., 26, 643-696.

Matmon, A., D. Schwartz, R. Finkel, S. Clemmens, and T. Hanks (2005), Dating offset fans along the Mojave section of the San Andreas fault using cosmogenic 26Al and 10Be, Geol. Soc. Am. Bull., 117, 795-807.

Middleton, R., L. Brown, B. Dezfouly-Arjomandy, and F. Klein (1993), On Be-10 standards and the half-life of Be-10, Nucl. Instrum. Methods Phys. Res., B82, 399-408.

Milne, G. A., A. J. Long, and S. E. Bassett (2005), Modelling Holocene relative sea-level observations from the Caribbean and South America, Quat. Sci. Rev., 24, 1183-1202.

Murauchi, S., and W. J. Ludwig (1980), Crustal structure of the Japan Trench: The effect of subduction of ocean crust, in Initial Reports of the Deep sea Drilling Project, 56 and 57: Part 1), edited by M. Langseth and H. Okada, pp. 463-469, U.S. Government Printing Office, Washington, D. C

Nelson, A. R., and W. F. Manley (1992), Holocene coseismic and aseismic uplift of Isla Mocha, south-central Chile, Quat. Int., 15/16, 61-76.

Olson, A. A. (1932), Contribution to the Tertiary paleontology of northern Peru: Part 5. The Peruvian Miocene, Bull. Am. Paleontol., 19, 264 pp.

Ortlieb, L., S. Barrientos, and N. Guzman (1996), Co-seismic coastal uplift and coralline algae record in northern Chile: The 1995 Antofagasta earthquake case, Quat. Sci. Rev., 15, 949-960.

Ota, Y., and M. Yamaguchib (2004), Holocene coastal uplift in the western Pacific Rim in the context of late Quaternary uplift, Quat. Int., 120, $105-$ 117.

Ozawa, S. (2002), Detection and monitoring of ongoing aseismic slip in the Tokai region, central Japan, Science, 298, 1009-1012.

Pedoja, K. (2003), Les terrasses marines de la marge nord andine (Equateur et Nord Perou): Relations avec le contexte géodynamique. PhD, Paris 6 University.
Peltzer, G., P. Rosen, F. Rogez, and K. Hudnut (1996), Postseismic rebound in fault step-over caused by pore fluid flow, Science, 273, 1202-1204.

Pilger, R. H. (1981), Plate reconstructions, aseismic ridges, and low-angle subduction beneath the Andes, Geol. Soc. Am. Bull., 92, 448-456.

Plafker, G. (1969), Tectonics of the March 27, 1964, Alaska earthquake, U.S. Geol. Surv. Prof. Pap., 543, 74 pp.

Raisbeck, G. M., F. Yiou, D. L. Bourles, J. Lestringuez, and D. Deboffle (1987), Measurements of ${ }^{10} \mathrm{Be}$ and ${ }^{26} \mathrm{Al}$ with a Tandetron AMS facility, Nucl. Instrum. Methods Phys. Res., B29, 22-26.

Raisbeck, G. M., F. Yiou, D. L. Bourles, E. T. Brown, D. Deboffle, P. Jouhanneau, J. Lestringuez, and Z. Q. Zhou (1994), The AMS facility at Gif-sur-Yvette: Progress, perturbations and projects, Nucl. Instrum. Methods Phys. Res., B92, 43-46.

Ranero, C. R., and R. von Huene (2000), Subduction erosion along the Middle America convergent margin, Nature, 404, 748-752.

Reilinger, R. E. (2000), Coseismic and postseismic fault slip for the 17 August $1999, M=7.5$, Izmit, Turkey earthquake, Science, 289, 1519-1524.

Ruff, L. J., and B. W. Tichelaar (1996), What controls the seismogenic plate interface in subduction zones?, in Subduction, top to bottom, edited by G. E. Bebout, D. W. Scholl, S. H. Kirby, and J. P. Platt, pp. 105-111, Geophys. Monogr. Series 96, AGU, Washington, D. C.

Savage, J. C. (1983), A dislocation model of strain accumulation and release at a subduction zone, J. Geophys. Res., 88, 4984-4996.

Scholl, D. W., R. von Huene, T. L. Vallier, and D. G. Howell (1980), Sedimentary masses and concepts about tectonic processes at underthrust ocean margin, Geology, 8, 564-568.

Sheperd, G. L., and R. Moberly (1981), Coastal structure of the continental margin northwest Peru and southwest Ecuador, In Nazca Plate: Crustal formation and Andean convergence, edited by L. D. Kulm, J. Dymond, E. J. Dasch, D. M. Hussong, and R. Roderick, pp. 351-391, Mem. Geol. Soc. Am. 154.

Shreve, R. L., and M. Cloos (1986), Dynamics of sediment subduction, melange formation, and prism accretion, J. Geophys. Res., 91, 10,22910,245 .

Song, T.-R. A., and M. Simons (2003), Large trench-parallel gravity variations predict seismogenic behavior in subduction zones, Science, 301, $630-633$.

Sosson, M., J. Bourgois, and B. Mercier de Lepinay (1994), SeaBeam and deep-sea submersible Nautile surveys in the Chiclayo canyon off Peru: Subsidence and subduction-erosion of an Andean type convergent margin since Pliocene time, Mar. Geol., 118, 237-256.

Stone, J. O. (2000), Air pressure and cosmogenic isotope production, J. Geophys. Res., 105, 23,753-23,759.

Suess, E., R. von Huene, and Leg 112 shipboard scientists (1988), Ocean Drilling Program Leg 112, Peru continental margin: Part 2. Sedimentary history and diagenesis in a coastal upwelling environment, Geology, 16, 939-943.

Sunamura, T. (1992), Geomorphology of rocky coasts, edited by E. C. F. Bird, John Wiley, Hoboken, N. J.

Taylor, F. W., et al. (2005), Rapid forearc uplift and subsidence caused by impinging bathymetric features: Examples from the New Hebrides and Solomon arcs, Tectonics, 24, TC6005, doi:10.1029/2004TC001650.

Thatcher, T. (1984), The earthquake deformation cycle at the Nankai trough, southwest Japan, J. Geophys. Res., 89, 3087-3101.

Thatcher, W. (1986), Cyclic deformation related to great earthquakes at plate boundary, Bull. R. Soc. N. Z., 24, 245-272.

Thornburg, T. M. (1988), Seismic stratigraphy of Peru forearc basins, in Atlas of the Ocean Margin Drilling Program, Peru continental margin, Region IV, edited by D. M. Hussong et al., pp. 1-8, Marine Science International, Woods Hole.

Thornburg, T. M., and L. D. Kulm (1981), Sedimentary basins of the Peru continental margin: Structure, stratigraphy, and Cenozoic tectonics from $6^{\circ} \mathrm{S}$ to $16^{\circ} \mathrm{S}$ latitude, in Nazca Plate: Crustal formation and Andean convergence, edited by L. D. Kulm, J. Dymond, E. J. Dasch, D. M. Hussong, and R. Roderick, pp. 469-508, Mem. Geol. Soc. Am., 154.

Tichelaar, B. W., and L. J. Ruff (1993), Depth of seismic coupling along subduction zones, J. Geophys. Res., 98, 2017-2037.

Travis, R. B., G. Gonzales, and A. Pardo (1976), Hydrocarbon potential of coastal basins of Peru, in Circum Pacific Energy and Mineral Resources, edited by M. T. Halbouty, J. C. Maher, and H. M. Lian, pp. 331-338, A. A. P. G. Mem., 25

Trenkamp, R., J. N. Kellog, T. Freymuller, and P. H. Mora (2002), Wide plate margin deformation, southern central America and northwestern South America, CASA GPS observations, J. South Am. Earth Sci., 15, $157-171$.

Van der Wateren, F. M., and T. J. Dunai (2001), Late Neogene passive margin denudation history-cosmogenic isotope measurements from the central Namib desert, Global Planet. Change, 30, 271-307.

Vannucchi, P., C. Ranero, S. Galeotti, S. M. Straub, D. Scholl, and K. McDougall-Ried (2003), Fast rates of subduction erosion along the 
Costa Rica Pacific margin: Implications for nonsteady rates of crustal recycling at subduction zones, J. Geophys. Res., 108(B11), 2511, doi:10.1029/2002JB002207.

Villemant, B., and N. Feuillet (2003), Dating open systems by the ${ }^{238} \mathrm{U}_{-}{ }^{234} \mathrm{U}_{-}{ }^{230} \mathrm{Th}$ method: Application to Quaternary reef terraces, Earth Planet. Sci. Lett., 210, 105-118.

von Huene, R., and C. R. Ranero (2003), Subduction erosion and basa friction along the sediment starved convergent margin off Antofagasta, Chile, J. Geophys. Res., 108(B2), 2079, doi:10.1029/2001JB001569.

von Huene, R., and D. W. Scholl (1991), Observations at convergent margins concerning sediment subduction, subduction erosion and the growth of continental crust, Rev. Geophys., 29, 279-316.

von Huene, R., E. Suess, and Leg 112 shipboard scientists (1988), Ocean Drilling Program Leg 112: Part 1. Tectonic history, Geology, 16, 934 938.

von Huene, R., J. Bourgois, J. Miller, and G. Pautot (1989), A large tsunamogenic landslide and debris flow along the Peru trench, J. Geophys. Res., 94, 1703-1714.

von Huene, R., C. R. Ranero, W. Weinrebe, and K. Hinz (2000), Quaternary convergent margin tectonics of Costa Rica, segmentation of the Cocos plate, and Central American volcanism, Tectonics, 19, 314-334.

Wang, K., and Y. Hu (2006), Accretionary prisms in subduction earthquake cycles: The theory of dynamic Coulomb wedge, J. Geophys. Res., 111, B06410, doi:10.1029/2005JB004094.
Winograd, I. J., J. M. Landwehr, K. R. Ludwig, T. B. Tyler, and A. C. Riggs (1997), Duration and structure of the past four interglaciations, Quat. Res., 48, $141-154$

Witt, C., J. Bourgois, F. Michaud, M. Ordoñez, N. Jimenez, and M. Sosson (2006), Development of the Gulf of Guayaquil (Ecuador) during the Quaternary as an effect of the North Andean Block tectonic escape, Tectonics, 25, TC3017, doi:10.1029/2004TC001723.

F. Bigot-Cormier, Géosciences Azur, UMR 6526, Université de Nice, Parc Valrose, F-06108, Nice Cedex 02, France. (florence.bigot@unice.fr)

J. Bourgois, Géosciences Azur, UMR 6526, Centre National de la Recherche Scientifique and Institut de Recherche pour le Développement, Université de Paris 6, Case 120, 4, place Jussieu, F-75252, Paris Cedex 5, France. (bourgois@ccr.jussieu.fr)

D. Bourles and R. Braucher, Centre Européen de Recherche et d'Enseignement des Géosciences de l'Environnement, Université AixMarseille III, Europôle Méditerranéen de l'Arbois, BP 80, F-13545, Aix-enProvence Cedex 04, France. (bourles@cerege.fr; braucher@cerege.fr)

O. Dauteuil, Géosciences Rennes, Université de Rennes1, Campus de Beaulieu, F-35042, Rennes Cedex, France. (olivier.dauteuil@univrennes1.fr)

F. Michaud and C. Witt, Géosciences Azur, UMR 6526, Observatoire Océanologique de Villefranche-sur-Mer, La Darse, BP 48, F-06235, Villefranche-sur-Mer Cedex, France. (michaud@uio.satnet.net; witt@ geoazur.obs-vlfr.fr) 